Thaynan Fernandes Cunha Martins

\title{
Análise da eficiência da PCR com identificação específica do agente etiológico para o diagnóstico da Leishmaniose Visceral Canina
}

Dissertação apresentada ao Instituto de Medicina Tropical de São

Paulo da Universidade de São Paulo para a obtenção do título de Mestre em Ciências.

Área de concentração: Doenças Tropicais e Saúde Internacional

Orientador: Prof. Dr. Paulo C. Cotrim

\section{São Paulo}

2013 
Ficha catalográfica

Preparada pela Biblioteca do Instituto de Medicina Tropical de São Paulo da Universidade de São Paulo (C) Reprodução autorizada Universidade de São Paulo

Martins, Thaynan Fernandes Cunha

Análise da eficiência da PCR com identificação específica do agente etiológico para o diagnóstico da leishmaniose visceral canina / Thaynan Fernandes Cunha Martins. - São Paulo, 2013.

Dissertação (Mestrado) - Instituto de Medicina Tropical de São Paulo da Universidade de São Paulo para obtenção do título de Mestre em Ciências.

Área de concentração: Doenças Tropicais e Saúde Internacional Orientador: Paulo Cesar Cotrim 
Dedico este trabalho a minha mãe Eliane, a minha irmã Pothyra e a minha avó Dejanira (in memorian), pelo incentivo, apoio, e pelo amor e carinho em todos os momentos da minha vida. 
Dedico este trabalho a Edite Yamashiro-Kanashiro, pois sem este apoio, confiança, credibilidade e ajuda em todos os momentos, nada disso seria possível. 


\section{AGRADECIMENTOS}

Ao meu orientador, Prof. Dr. Paulo Cotrim pela orientação durante o desenvolvimento do trabalho, pelos ensinamentos científicos, profissionais e pessoais, pela amizade e confiança, e a oportunidade de fazer parte do seu grupo de pesquisa, ajudando a me desenvolver como profissional e a conquistar grandes oportunidades na área científica. Obrigada pela amizade e confiança que sempre demonstrou ter por mim.

À Edite Yamashiro-Kanashiro pela orientação, atenção, dedicação com o projeto de pesquisa, pelo acolhimento, e pelos ensinamentos dentro e fora do laboratório. Agradeço também pela amizade, o carinho e confiança durante todos esses anos de convívio.

Ao Dr. Ângelo pela disponibilização das amostras de cães sorologicamente positivos, por participar ativamente do projeto, por me co-orientar em relação ao desenvolvimento do projeto e por ser um amigo dentro e fora do Laboratório. Sem a sua participação esse trabalho não poderia ser desenvolvido.

À Mussya Rocha pela ajuda durante todo o experimento, pela atenção com o trabalho, pela dedicação em conseguir coletar as amostras do grupo de cães do controle negativo, indo e voltando toda semana da cidade de Embu das Artes. Agradeço também pela amizade, pelos ensinamentos pessoais, profissionais e pela amizade.

Ao Dr. J. J. Shaw por gentilmente ceder as cepas de Leishmania (L.) amazonensis (MHOM/ BR/ 1973 / M2269), Leishmania (V.) braziliensis (MHOM/BR/1975/M2903) e Leishmania (L.) infantum-chagasi (MCER/BR/1918/M6445), utilizadas como controle de todas as reações de PCR.

Agradeço a Dra Maria Carmem Arroyo, por me ajudar com todas as análises estatísticas desse projeto.

Agradeço aos amigos e alunos do Laboratório de Soroepidemiologia e Imunobiologia, em especial a Marcela Satow por ser minha primeira "orientadora" com muita paciência, sabedoria e amizade; a Juliana Aoki pelas dicas, ajuda e paciência durante 
os experimentos, e pela amizade dentro e fora do laboratório; a Luciana Camizoti pela companhia, pela paciência e amizade. Agradeço também a Flaviane Pinho, Luiza Reis, Eduardo Sanchez, William Roldam, Lilian Farias, Ive Maíra Dantas, Amanda Silva, Marilda Guimarães e Yana Rosa por sempre estarem presentes e dispostos a ajudar sempre que necessário.

As Professoras Dra. Hiro Goto, Dra Thelma Okay e, por me ajudarem com desenvolvimento do projeto, emprestarem sue laboratório para experimento e por participarem como membro da qualificação e professora do curso de pós-graduação respectivamente.

Aos Professores e funcionários do Laboratório de Soroepidemiologia e Imunobiologia em especial a Dra. Thelma Okai, Dra Sandra Moraes, Dra Sandra Soares, Dra Guita Rubinsky, Dra Kelly Kanufre, Dr. Walter Ferreira, pelo convívio e apoio e ensinamentos durante o desenvolvimento do trabalho.

Aos funcionários do Laboratório de Soroepidemiologia e Imunobiologia em especial ao Jonatas Rodirgues, Christiane Ozaki, Eunice Bonfim, Dona Nilzete, Elizabete Ourique, Egon Stach, Renato Racickas, pelo convívio, pela amizade e apoio sempre que foi presiso.

A Professora Eufrosina Setsuo Umezawa pela oportunidade de continuar os experimentos no seu laboratório, disponibilizando seus materiais, e providenciando todas as condições necessárias para continuarmos os experimentos durante a época de reforma. Agradeço também pela amizade e confiança que sempre demonstrou por $\operatorname{mim}$.

Agradeço aos funcionários do Laboratório de protozologia, em especial a Monica de Paula Souza, ao Luciano Monteiro da Silva, pela paciência e atenção em me disponibilizarem todas as condições de trabalho necessárias para continuar os experimentos.

Agradeço ao Norival Kesper Jr. e a Marilda Savioa pelo carinho e amizade durante todo o tempo de trabalho e convívio no Laboratório de Protozoologia. 
Ao Dr. Andrés Jimenez Galisteo Jr. por sempre me ajudar com os experimentos de Real-time PCR, com muita paciência e disponibilidade.

À Eliane Araujo por toda a ajuda com os documentos da pós-graduação, além dos esforços em me avisar pessoalmente sobre datas e prazos para entrega de documentos. Agradeço pela paciência durante as minhas entrevistas online e pela ajuda na entrega final desse projeto.

Aos Técnicos de Informática Fábio e Daniel, pela ajuda fundamental durante todo o processo de entrevistas online e pela dedicação com os chamados para suporte de informática que eu abri durante esses anos de pesquisa no IMT.

Agradeço aos meus amigos de "laboratório" Jonatas Cristian Rodrigues, Lília Spaleta Targa, Leandro Emídio Teixeira, Lídia Yamoto, e Wilson Domingues pelo convívio e pelo apoio que sempre me deram durante a vida laboratorial e pessoal.

Agradeço aos meus Tios Jorge Brito, Neuza Brito, Ivan Leite e Lina Brito pelo carinho, dedicação e principalmente por me incentivarem a continuar na área da pesquisa científica.

Agradeço ao meu amigo Ivan Henrique Yoshida, que sempre me apoiou a continuar e seguir os meus sonhos como biomédica. Sendo sempre um exemplo de biomédico para mim.

Agradeço ao Kai Kegelmann pela ajuda durante o desenvolvimento do projeto de mestrado e por todo apoio e paciência durante o período de pesquisa e conclusão da dissertação.

À FAPESP, CAPES, CNPq e LIM 38 pelo apoio e financiamento

Finalmente agradeço a todos que contribuíram direta ou indiretamente para a conclusão deste trabalho. Obrigada!! 
"A verdadeira viagem do descobrimento não consiste em procurar novas paisagens, mas em ter novos olhos"

(Marcel Proust) 


\section{RESUMO}

Martins TFC. Análise da eficiência da PCR com identificação específica do agente etiológico para o diagnóstico da Leishmaniose Visceral Canina. São Paulo: Instituto de Medicina Tropical de São Paulo; 2013.

Atualmente, um dos grandes problemas relacionados à leishmaniose é a falta de um diagnóstico específico capaz de indentificar e diferenciar espécies de Leishmania com rapidez e precisão. O desenvolvimento de métodos moleculares como a Reação em Cadeia da Polimerase (PCR), possibilita que o diagnóstico da Leishmaniose Visceral Canina (LVC) possa se tornar mais preciso e, eventualmente, de fácil execução, uma vez que limitações importantes relacionadas à sensibilidade e especificidade desta técnica ainda são descritas, principalmente quando se utiliza amostras clínicas.

Com o intuito de melhor avaliar a eficiência da PCR para o diagnóstico da LVC, foram selecionadas diferentes amostras clínicas (baço, aspirado de linfonodo, pele sem lesão, pele com lesão e amostras de sangue) de 26 cães com sorologia positiva para leishmaniose submetidos à eutanásia pelo Serviço de Vigilância Epidemiológica do município de Embu das Artes - SP. Realizamos uma análise comparativa entre a PCRRFLP kDNA-Haell e PCR-RFLP hsp70-BsaJl/EcoRIl com dois métodos diagnósticos tradicionais (parasitológico direto, e cultura in vitro). Amostras clínicas de 28 cães com sorologia negativa para LVC da mesma região foram utilizadas como controle negativo das reações. Notamos que a PCR aprensentou maior sensibilidade em todas as amostras clínicas testadas quando comparadas aos métodos tradicionais. Os 
resultados apontam que a PCR-RFLP kDNA-Haell é a mais eficiente para o diagnóstico da LVC, com um índice de $96,15 \%$ de positividade nas amostras de pele com lesão. Quanto à discriminação da espécie de Leishmania envolvida na infecção, nossos resultados de PCR-RFLP kDNA-Haell indicam Leishmania chagasi-infantum como o agente etiológico envolvido na infecção e transmissão canina na cidade de Embu das Artes. Por outro lado, a análise da PCR em Tempo Real (qPCR), mostrou que algumas amostras de sangue não apresentavam o padrão associado à Leishmania chagasi-infantum, podendo indicar uma co-infecção com outras parasitoses caninas. Nosso grupo também acompanhou 184 crianças de 4 a 10 anos de idade (população de risco) residentes da mesma região de transmissão autóctone da doença canina, como também foi realizado um levantamento das espécies de flebotomíneos da região (pela SUCEN). Até o momento, não foi encontrado nenhum caso da doença humana, nem a principal espécie transmissora do parasito (Lutzomiya longipalpis). Acreditamos que esses resultados possam contribuir significativamente para aprimorar o diagnóstico e a identificação das espécies Leishmania na LVC.

Descritores: kDNA. Reação de cadeia por polimerase. Leishmaniose visceral animal. Amostras clínicas. Leishmania. Técnicas de diagnóstico molecular. 


\begin{abstract}
Martins TFC. Evaluation of PCR techniques for the identification and characterization of Visceral Leishmaniasis in different tissues of seropositive dogs (dissertation). São Paulo: Instituto de Medicina Tropical de São Paulo da Universidade de São Paulo; 2013.
\end{abstract}

Currently, one of the major problems related to leishmaniasis is the lack of a specific diagnosis capable of identifying and differentiating Leishmania species quickly and accurately. The development of molecular methods such as Polymerase Chain Reaction ( PCR ) allows the diagnosis of Canine Visceral Leishmaniasis (CVL) to become more accurate and eventually, easy to perform, since that important limitations in terms of sensitivity and specificity of this technique are being described especially when using clinical samples.

In order to better evaluate the efficiency of PCR for the diagnosis of CVL, we selected different clinical samples (spleen, lymph node aspirate, skin with and without lesions and blood samples) from 26 dogs with positive serology for leishmaniasis submitted to euthanasia by the Agency of Epidemiological Surveillance of Embu das Artes - SP. Therefore, we performed a comparative analysis between the kDNAPCR-RFLP Haell and hsp70PCR-RFLP BsaJl/EcoRII with two traditional diagnostic methods (direct parasitological test, and in vitro culture). Additionally, clinical samples from 28 dogs with negative serology for CVL in the same region were used as negative reactions control. We noted that the PCR showed greater sensitivity in all clinical samples tested when compared with traditional methods. The results indicate that the kDNAPCR-RFLP 
HaellI is the most efficient test for the diagnosis of CVL, with a positivity index of 96.15 $\%$ in skin lesions samples. Related to the discrimination of the Leishmania species involved in the infection, our results of kDNAPCR-RFLP Haelll indicate Leishmania infantum chagasi as the agent involved in canine infection in Embu das Artes city. Moreover, the analysis of real-time PCR (qPCR) showed that some blood samples has not showed the same pattern associated with Leishmania infantum chagasi suggesting a possible co-infection with other canine parasite. Our group also followed 184 children between 4 to 10 years old (risk population) living in the same region of autochthonous transmission of canine disease, as well a survey was conducted on the sandfly species in the region (by SUCEN). So far, we found no human infection, nor the main species involved in the transmission of the parasite (Lutzomyia longipalpis). We believe that these results can significantly contribute to the improvement of the diagnosis and identification of Leishmania species involved in the CVL worldwide.

Descriptors: kDNA. Polymerase chain reaction. Visceral leishmaniasis animals. Clinical specimens. Leishmania. Molecular diagnostic techniques. 


\section{LISTA DE FIGURAS}

Página

Figura 1 - (A) Lâmina de pele com lesão do cão EB001 corada com HE; (B) Lâmina de "imprinting" de pele com lesão do cão EB001 corada com Giemsa. Lâminas analisadas em microscópio óptico NIKON Eclipse E200 com objetiva de 100X em imersão

Figura 2 - Produtos da reação de kDNA-PCR seguidos por digestão enzimática com a enzima de restrição Hae III. L- Peso molecular Ultra-Low Range Fermentas; 1-L. amazonenses; 2- L. braziliensis; L- chagasi.

Figura 3 - $\quad$ Produtos da reação de kDNA-PCR seguidos por digestão enzimática com a enzima de restrição Hae III. L- Peso molecular Ultra-Low Range Fermentas;1- L. baziliensis; 2 EB001 baço; 3-EB002 baço; 4-EB003 baço;5- EB004 baço; 6-EB005 baço; 7-EB006 baço;8- EB007 baço

Figura 4 - $\quad$ Produtos da reação de hsp70-PCR seguidos por digestão enzimática com a enzima de restrição BsaJl. L- Peso molecular 50pb Low Range Fermentas; 1-L. chagasi. 2EB001 baço; 3-EB003 baço; 4- EB005 baço; 5- EB007 baço

Figura 5 - $\quad$ Produtos da reação de hsp70-PCR seguidos por digestão enzimática com a enzima de restrição BsaJl e EcoRII. LPeso molecular 50pb Low Range Fermentas; 1- Controle negativo; 2-EB002 Linfonodo; 3-EB003 Linfonodi; 4- EB005 Linfonodo;5- EB007 linfonodo.

Figura 6 - Curva Padrão das amostras de DNA de LeishmaniaResultado da amplificação do DNA de Leishmania chagasi pela técnica de Real-Time PCR na concentração de $10^{8}$ parasitos por $\mathrm{mL}$ a 10 parasitos por $\mathrm{mL}$.

Figura 7 - Resultado da Curva Melting da Real-Time PCRDissociação da Dupla fita de DNA após a amplificação do DNA de Leishmania amazonenses.

Figura 8 - Resultado da Curva Melting da Real-Time PCRDissociação da Dupla fita de DNA após a amplificação do DNA de Leishmania brasiliensis 
Figura 9 - Resultado da Curva Melting da Real-Time PCR-

Dissociação da Dupla fita de DNA após a amplificação do DNA de Leishmania chagasi.

Figura 10 - Resultado da Curva de Melting da Real-Time PCRDissociação da Dupla fita de DNA após a amplificação do DNA de amostras de sangue dos cães soropositivos para LVC.

Figura 11 - Resultado da Curva de Melting da Real-Time PCR78 Dissociação da Dupla fita de DNA após a amplificação do DNA das amostras dos tecidos de pele sem lesão coletadas dos cães com sorologia positiva para LVC 


\section{LISTA DE TABELAS}

Página

Tabela 1 - Classificação clínica dos cães $\quad 51$

Tabela 2 - Resultado da cultura in vitro das amostras de diferentes 53 tecidos dos 26 cães eutanasiados.

Tabela 3 - $\quad$ Resultado da pesquisa de formas amastigotas em lâminas coradas com Giemsa.

Tabela 4 - Resultado da pesquisa de formas amastigotas em lâminas coradas com HE.

Tabela 5 - $\quad$ Resultados da reação de kDNA-PCR nos diferentes tecidos de biopsia canina

Tabela 6 - Resultados da reação de hsp70-PCR nos diferentes tecidos de biopsia canina.

Tabela 7 - Comparação entre as técnicas de cultura in vitro do parasito, Pesquisa direta em lâminas coradas com Giemsa e a reação de PCR (kDNA e hsp70) nos diferentes tecidos dos cães soropositivos.

Tabela 8 - $\quad$ Resultados da kDNA-PCR comparados aos resultados do teste parasitológico direto* de cada um dos 26 cães soropositivos.

Tabela 9 - $\quad$ Resultados da hsp70-PCR comparados aos resultados do teste parasitológico direto* de cada um dos 26 cães soropositivos.

Tabela 10 - Comparação entre os diferentes tecidos analisados nos testes moleculares (kDNA-PCR e hsp70-PCR) utilizando os testes parasitológicos como padrão ouro da reação

Tabela 11 - Especificidade dos testes de kDNA-PCR e hsp70-PCR em cada um dos tecido coletados dos cães soropositivos em comparação com o parasitológico direto 


\section{LISTA DE ABREVIATURAS, SIGLAS E SÍMBOLOS}

$\begin{array}{ll}\text { B.O.D } & \text { do inglês "Biochemical oxygen demand" } \\ { }^{\circ} \mathrm{C} & \text { Graus Celsius } \\ \mathrm{C}_{\mathrm{T}} & \text { do inglês "threshold cycle" } \\ \mathrm{CCZ} & \text { Centro de controle de zoonoses } \\ \text { DMSO } & \text { Dimetilsulfóxido } \\ \text { DNA } & \text { do inglês "desoxyribonucleic acid" } \\ \text { dNTP } & \text { Mistura dos quatro deoxinucleotideos trifosfato } \\ \text { EDTA } & \text { do inglês "Ethylene diamine tetracetic acid" } \\ \text { ELISA } & \text { do inglês "Enzyme-linked immunosorbent assay" } \\ \text { et al. } & \text { e outros } \\ \text { FUNASA } & \text { Fundação Nacional da Saúde } \\ \text { Giemsa } & \text { Método de coloração "May-Grunwald-Giemsa" } \\ \text { HE } & \text { Método de colaração Hematoxilina-Eosina } \\ \text { HEPES } & \text { N-2-hidroxietilpiperazina-N'-2-ácido etanosulfônico } \\ \text { hsp70 } & \text { do inglês "70 kilodalton heat shock protein" } \\ \text { IFI } & \text { Imunofluorescência indireta } \\ \text { K2EDTA } & \text { di-potássio EDTA } \\ \text { kDNA } & \text { DNA do cinetoplato } \\ \text { Km } & \text { Quilômetros } \\ \text { LVC } & \text { Leishmaniose visceral canina } \\ \text { M } & \text { Molar } \\ \text { MgCl } & \text { Cloreto de Magnésio } \\ \text { min } & \text { Minutos } \\ \text { mL } & \text { Mililitro } \\ \text { Mg } & \text { Miligramas } \\ \text { Ng } & \text { Nanogramas } \\ \text { OMS } & \text { Organização mundial da Saúde } \\ \text { P } & \text { Índice de probabilidade } \\ & \end{array}$




$\begin{array}{ll}\text { Pb } & \text { Pares de base } \\ \text { PCR } & \text { do inglês "Polymerase chain reaction" } \\ \text { qPCR } & \text { PCR quantitativa em Tempo Real } \\ \text { RFLP } & \text { do inglês "Restriction fragment length polymorphism" } \\ \text { RNase } & \text { Ribonuclease } \\ \text { SDS } & \text { Dodecil Sulfato de Sódio } \\ \text { SP } & \text { São Paulo } \\ \text { SVE } & \text { Serviço de Vigilância Epidemiológica } \\ \text { TAE } & \text { Tampão Tris-Acetato-EDTA } \\ \text { TE } & \text { Tampão de eluição } \\ \text { TM } & \text { do inglês "Temperature of mealting" } \\ \text { U } & \text { Unidades } \\ \text { UI } & \text { Unidade de medida internacional } \\ \text { UV } & \text { Luz ultraviolet } \\ V & \text { Volts } \\ V & \text { Volume } \\ \mu \mathrm{g} & \text { Micrograma } \\ \mu L & \text { Microlitro } \\ \mu M & \text { Micromolar }\end{array}$




\section{SUMÁRIO}

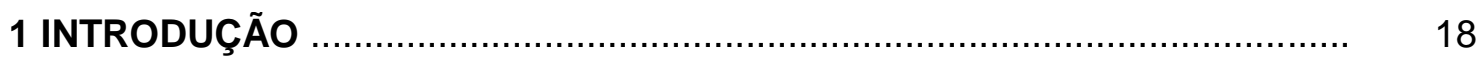

1.1 Parasito e ciclo biológico .................................................................. 18

1.2 Aspectos clínicos e epidemiológicos ....................................................... 20

1.2.1 Características epidemiológicas no Brasil ............................................... 20

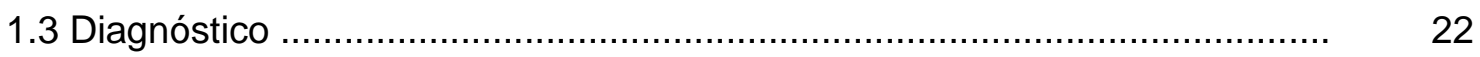

1.3.1 Diagnóstico clínico da leishmaniose visceral canina (LVC) ......................... 24

1.3.2 Diagnóstico parasitológico da LVC .................................................... 25

1.3.3 Diagnóstico imunológico da LVC ....................................................... 27

1.3.4 Diagnóstico molecular - PCR para LVC ............................................ 28

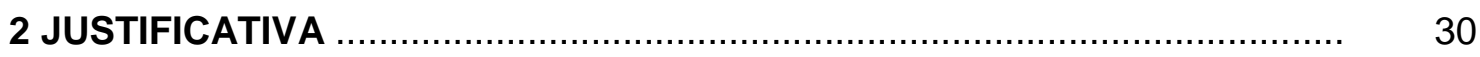

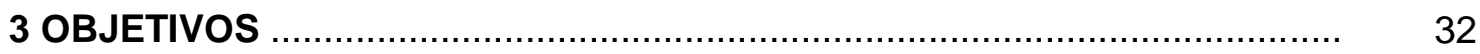

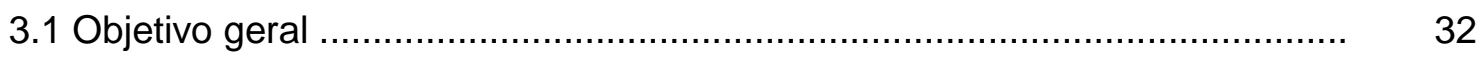

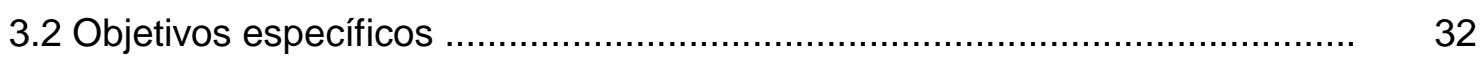

4 MATERIAIS E MÉTODOS ............................................................ 33

4.1 Inquérito sorológico realizado na cidade de Embu das Artes; Coleta das 33 amostras de tecido; Acompanhamento clínico da população em risco

4.1.1 Inquérito sorológico ........................................................................... 33

4.1.2 Coleta das amostras de tecidos dos cães ................................................. 34

4.1.3 Investigação de casos clínicos da população humana em risco ................... 35

4.2 Teste de Cultura de parasitos in vitro .................................................... 36

4.3 Teste Direto - Estudo histológico por HE e Giemsa ................................. 37

4.4 Extração de DNA das amostras analisadas ............................................. 38

4.4.1 Extração do DNA de cultura de promastigota ....................................... 38

4.4.2 Extração do DNA das biopsias de tecidos ................................................ 39

4.4.3 Extração do DNA de sangue ............................................................ 40

4.5 Padronização da técnica de amplificação de DNA por PCR .......................... 41

4.6 Digestão enzimática do produto de DNA amplificado por PCR visando à 44 identificação da espécie do parasito

4.7 Padronização da técnica de PCR em tempo real ...................................... 45

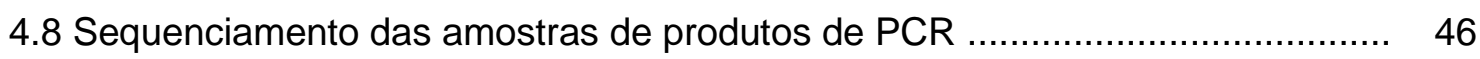




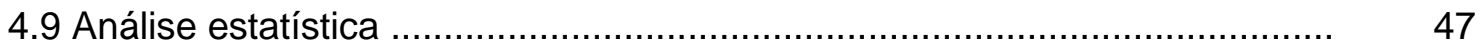

4.9.1 Teste Chi-quadrado $\chi^{2}$............................................................... 47

4.9.2 Teste de McNemar ................................................................................ 48

4.9.3 Teste exato de Fisher .................................................................. 49

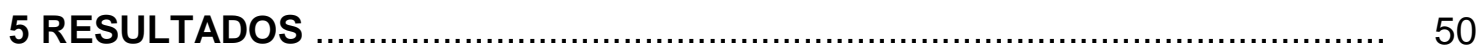

5.1 Inquérito sorológico realizado em Embu das Artes; Avaliação clínica dos 50 cães; Coleta das amostras de tecido

5.2 Acompanhamento clínico da população de risco ............................................ 51

5.3 Teste de cultura in vitro das biópsias ...................................................... 52

5.4 Teste parasitológico direto para a pesquisa de formas amastigotas nas 53 amostras de tecido

5.5 Resultados das reações de PCR …................................................... 57

5.5.1 Resultados da kDNA- PCR com as diferentes amostras de tecido .............. 57

5.5.2 Resultados da hsp70- PCR com as diferentes amostras de tecido .............. 59

5.6 Comparação entre os resultados da cultura in vitro, exame direto e PCR dos 61 cães positivos

5.6.1Comparação entre os resultados das PCRs com o teste parasitológico direto 63 em cada um dos cães positivos

5.7 Identificação de espécies de Leishmania com a técnica de PCR-RFLP ........... 68

5.8 Resultados da PCR em Tempo Real (qPCR) ............................................. 72

5.9 Resultados do Sequenciamento dos Produtos de PCR discordantes na 79 Reação de kDNA-PCR

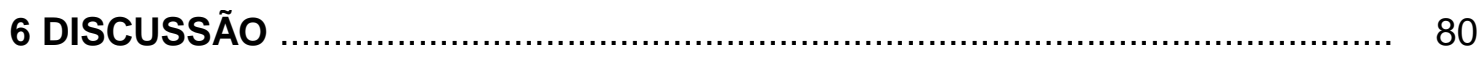

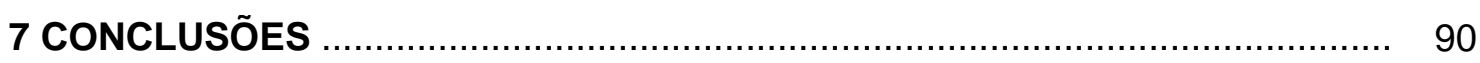

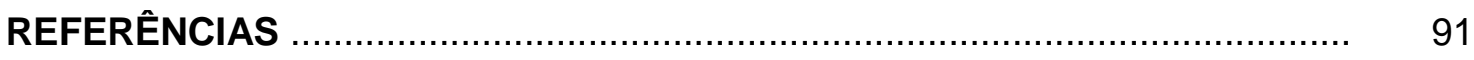

ANEXO A - Comitê de Ética do IMT/USP .................................................. 99 
Martins TFC

\section{INTRODUÇÃO}

A leishmaniose é uma doença infecto-parasitária causada por várias espécies de protozoários do gênero Leishmania, que acomete o homem e diversas espécies de mamíferos silvestres e domésticos (Gontijo e Carvalho, 2003). As formas clínicas são variadas e podem provocar lesões cutâneas, viscerais e lesões nas mucosas. Essa diferenciação na progressão da doença está relacionada com a espécie do parasito infectante e a suscetibilidade do hospedeiro, com a qual pode variar entre diferentes manifestações cutâneas à forma visceral da doença (Rey, 1991; Ashford et al., 2000).

Segundo a OMS (Organização Mundial de Saúde), estima-se que a prevalência da doença seja de 12 milhões de casos, com uma incidência anual de cerca de 2 milhões de novos casos, e aproximadamente 350 milhões de pessoas no mundo sob o risco de infecção pelo parasito, (OMS, 2013a). Atualmente, as leishmanioses ocorrem de forma endêmica em 88 países de quatro continentes. Apesar de sua importância na saúde pública, apenas 32 países fazem a notificação compulsória dos casos.

\subsection{Parasito e ciclo biológico}

Os protozoários causadores das leishmanioses apresentam duas formas morfologicamente distintas: a amastigota que apresenta um corpo circular, achatado, núcleo relativamente grande, redondo e central, presente no interior de macrófagos do 
Martins TFC

hospedeiro vertebrado mamífero; e a promastigota com núcleo central e cinetoplasto na região anterior, de onde emerge um longo flagelo, normalmente esta forma do parasito está presente no tubo digestivo do inseto vetor. Ambas as formas se multiplicam por divisão binária (Rey, 1991).

A transmissão ocorre pela picada de um inseto hematófago flebótomo de dois gêneros principais: Phlebotomus mais comuns na África, Ásia e Europa, e Lutzomyia encontrado nas Américas, sendo a espécie Lutzomyia longipalpis a mais frequentemente relacionada com a transmissão no Brasil. A fêmea do inseto flebotomíneo pica o hospedeiro vertebrado infectado, que ao realizar a ingestão de sangue adquire as formas amastigotas contidas no interior dos macrófagos, que se diferenciam em promastigotas procíclicas e posteriormente em promastigotas metacíclicas infectantes. Essas formas infectantes migram para a região da faringe e cavidade bucal do vetor, podendo ser inoculadas no hospedeiro vertebrado. Os metacíclicos são capturados principalmente por macrófagos, onde estes se diferenciam em formas amastigotas, multiplicando-se no interior da célula hospedeira, que se rompe liberando os amastigotas no meio intercelular amplificando o processo.

$\mathrm{Na}$ transmissão, os reservatórios animais tem participação vital, ocorrendo enquanto o parasitismo persistir na pele ou no sangue circulante desses animais. Os principais reservatórios mamíferos, e considerados mantenedores do ciclo da doença, são o cão (Canis familiaris), e a raposa (Dusycion vetulus); apesar do homem também poder atuar como fonte de infecção. 


\subsection{Aspectos clínicos e epidemiológicos}

Dentre todas as formas clinicas das Leishmanioses, a Leishmaniose Visceral (LV) é a forma mais severa, de caráter grave e crônico, sendo potencialmente fatal para o homem, com grau de letalidade podendo alcançar $10 \%$ se não tratada adequadamente (Neves, 2007; Desjeux, 2004).

De acordo com a Organização Mundial da Saúde (OMS), a LV é uma das principais endemias mundiais, afetando cerca de 500 mil pessoas / ano (OMS, 2013b). Neste cenário mundial a LV é endêmica em 62 países, sendo que $90 \%$ dos casos ocorrem na Índia, Sudão, Bangladesh e Brasil.

\subsubsection{Características epidemiológicas no Brasil}

No Brasil, a LV representa um sério problema de saúde pública devido à ampla expansão geográfica no país. A doença que era tipicamente rural passou a ter um caráter urbano no final dos anos de 1970 quando foram detectados casos da doença na capital do estado do Piauí, Teresina (OMS, 2013c).

Novos surtos vêm sendo descritos em diversas regiões. Entre o período de 2001 e 2005, foram reportados 15.340 casos de LV, e 196.239 casos de Leishmaniose Cutânea (LC), a forma mais branda da doença. A LV está distribuída em 20 Unidades Federadas (Nordeste 56\%, Sudeste 19\%, Norte 18\% e Centro-Oeste 7\%), enquanto 
que a LC está distribuída em todas as regiões (Norte 39\%, Nordeste 28\%, CentroOeste 17\%, Sudeste 14\% e Sul 2\%) (Brasil, 2013).

Segundo notificações do Ministério da Saúde, até 1997, não havia casos autóctones de LV no estado de São Paulo. Entretanto, a LV tem se tornado uma preocupação em decorrência do grande número de cidades paulistas apresentarem registros da doença em seres humanos ou cães. Em 2006, as cidades com os maiores números de casos registrados foram: Bauru (70), Dracena (40), Araçatuba (21) e Birigui (20). A cidade de São Paulo está, por enquanto, livre da leishmaniose, mas preocupa o fato de cidades vizinhas, como Embu das Artes e Cotia, terem registro da doença em cães, o principal reservatório urbano da doença, (Nunes et al., 2010).

Preocupando-se com a disseminação da doença, o Ministério da Saúde, por intermédio da Fundação Nacional da Saúde (FUNASA), e de Secretarias Estaduais e Municipais de Saúde realizam o Programa de Controle da Leishmaniose Visceral (PCLV).

A LV no Brasil é causada pelo protozoário L. infantum chagasi e transmitida pelo flebotomíneo Lutzomyia longipalpis. Tendo como os principais reservatórios que participam do ciclo zoonótico os canídeos selvagens e cães domésticos (o principal reservatório urbano). O PCLV tem como uma das medidas profiláticas o controle do reservatório canino através de inquéritos sorológicos, indicando a eutanásia dos cães sororreagentes, assim como a aplicação de inseticidas, e o diagnóstico e tratamento adequado dos casos humanos registrados.

A Vigilância epidemiológica é um dos componentes do PCLV, cujos objetivos são reduzir as taxas de letalidade e grau de morbidade através do diagnóstico precoce 
e tratamento adequado dos casos humanos, bem como diminuir os riscos de transmissão mediante controle da população de reservatórios e do agente transmissor.

Uma das mais importantes medidas de controle é voltada para a análise sorológica periódica em cães, uma vez que a enzootia canina tem precedido a doença humana (Cortada et al., 2004). Essa medida, no entanto, tem um impacto social importante, pois a população não colabora na realização dos testes sorológicos, uma vez que a conduta para um teste sorológico positivo é a eutanásia do animal. Braga e colaboradores, em 1994, enfatizam a importância dos parâmetros de sensibilidade e especificidade dos testes diagnósticos, quando avaliam o impacto da eliminação do cão frente à metodologia empregada. Sabe-se que os testes sorológicos atualmente recomendados pelo MS apresentam baixa especificidade (Mohammed et al., 1985; da Costa et al., 1991; Zanzarini et al., 2005).

\subsection{Diagnóstico}

O diagnóstico das leishmanioses abrange aspectos epidemiológicos, clínicos e laboratoriais, onde, frequentemente a associação de alguns desses elementos é necessária para se chegar ao diagnóstico final (Furtado, 1987, Gontijo e Carvalho, 2003). Porém, o diagnóstico definitivo para Leishmaniose está relacionado com a demonstração direta do parasito, comumente realizado através da visualização em microscópio óptico de formas amastigotas de Leishmania spp., e/ou pelo isolamento do parasito em meios de cultura in vitro. Estas técnicas tradicionais apresentam algumas 
Martins TFC

limitações em termos de sensibilidade, além de serem dependentes da experiência do técnico e de levarem muito tempo para a liberação do resultado.

Nos últimos anos avanços significativos têm sido obtidos nas técnicas de detecção e caracterização das espécies do parasito. A reação em cadeia da polimerase (PCR) descrita por Saiki (1985) consiste na síntese enzimática in vitro de sequências específicas de DNA através de uma série de ciclos a diferentes temperaturas (desnaturação das fitas de DNA, anelamento dos iniciadores e extensão da região flanqueada pelo iniciador). Este processo permite o acúmulo exponencial dos fragmentos delimitados pelos iniciadores gerando ao final da reação uma produção de milhões destes fragmentos. A utilização da PCR tem superado algumas desvantagens apresentadas pelos métodos tradicionais. Particularmente a PCR melhora a sensibilidade do teste em fases crônicas da doença tegumentar (Weigle et al., 2002), permite a utilização de amostras menos invasivas, como amostras de sangue, para o diagnóstico de LV (Mohammadiha et al., 2012; Antinori et al., 2007).

Atualmente, o método de PCR em tempo real também está sendo desenvolvido para identificação do parasito, sendo que além da identificação, pode também estimar a carga parasitária (Oryan et al. 2013; Toz et al., 2013; Weirather et. al, 2011; Quaresma et al., 2009), auxiliando assim, em estudos epidemiológicos, monitoramento do tratamento e testes de eficiência de drogas (Dujardin et al., 2002; Schönian et al., 2011). 


\subsubsection{Diagnóstico clínico da Leishmaniose Visceral Canina (LVC).}

O diagnóstico clínico da LVC é considerado difícil de ser realizado devido à variedade de sintomas da doença (Ferrer, 1999; Grandoni, 2005). Os achados clínicos são comuns a outras enfermidades, tornando o diagnóstico laboratorial ou parasitológico necessários para a confirmação da suspeita (Sivakumar, 2003; Feitosa, 2000).

Por outro lado, enquanto a prevalência da infecção em cães de áreas endêmicas pode chegar a $50 \%$ ou mais, a prevalência da doença clínica ocorre entre $3 \%$ e $10 \%$, demonstrando que a maioria dos cães infectados não desenvolvem os sintomas clássicos da LVC, como alopecia, eczema furfuráceo, onicogrifose, emagrecimento, ceratoconjuntivite e linfadenopatia, o que dificulta o diagnóstico. É importante salientar que as lesões de pele isoladas, semelhantes às encontradas na leishmaniose cutânea no homem, são de ocorrência rara nos cães (Lamothe, 2002). O período de incubação é bastante variável, de três meses a vários anos e os animais podem permanecer assintomáticos (Gomes, 2006).

Quando os cães apresentam características clínicas, os órgãos linfoides são alvo na doença. Os linfonodos encontram-se frequentemente enfartados, com hipertrofia dos folículos, intensa fibrose, seios dilatados e hiperplasia de macrófagos (Alencar, 1959; Reis et al., 2009). A esplenomegalia nem sempre está presente, podendo ser discreta, moderada ou intensa (Alencar, 1959, Reis et al., 2009). Este órgão apresenta uma diminuição de linfócitos na bainha linfoide periarteriolar e proliferação de macrófagos nesta região; hiperplasia folicular e aumento da polpa vermelha com agregados de macrófagos e plasmócitos (Keenan et al., 1984; Badaró \& 
Martins TFC

Duarte, 1996; Tafuri, et al., 2001). Na medula óssea percebe-se hiperplasia decorrente da proliferação de macrófagos que podem ou não conter parasitos (Keenan et al., 1984). A hiperplasia medular, principalmente de células brancas associada à identificação de macrófagos parasitados foi referido por Tafuri et al. (2001). O fígado, geralmente encontra-se aumentado de volume na LVC (Alencar, 1959; Reis et al., 2009), apresentando um infiltrado plasmo-linfocitário e hiperplasia das células de Küpffer (Keenan et al., 1984), porém sendo raro o achado do parasito (Duarte, et al., 1989).

A revisão sobre o diagnóstico da LVC realizado por Grandoni, 2002 refere que o diagnóstico clínico é difícil, uma vez que mais de $50 \%$ dos cães com infecção estabelecida e comprovada são aparentemente assintomáticos. Quando os sinais clínicos estão presentes, são variáveis, e podem mimetizar outras enfermidades, tornando o diagnóstico clínico um desafio real (Reis et al., 2009).

\subsubsection{Diagnóstico parasitológico da LVC.}

Segundo recomendação do Ministério da Saúde, o teste diagnóstico mais confiável é a observação direta do parasito, como já ressaltado. No entanto, mesmo quando realizado em material retirado da medula óssea e/ou de aspirados de linfonodo, a detecção do parasito é difícil exigindo um profissional qualificado.

Os achados histopatológicos são, por vezes, inespecíficos e caracterizam-se por uma reação inflamatória granulomatosa com presença de células mononucleares, reações estas comuns a várias outras dermatoses. Quando há poucas formas 
Martins TFC

amastigotas de Leishmania spp. nos tecidos, pode ser difícil estabelecer-se o diagnóstico somente pela histopatológica (Moreira et al., 2002).

Apesar dessas dificuldades, esse método diagnóstico é bastante utilizado devido a sua grande simplicidade, baixo custo e boa especificidade, representando um dos principais métodos tradicionais para o diagnóstico da LVC (Ashford, 2000; Weigle et al., 2002). Assim, como a cultura de tecidos, esses métodos baseiam-se na observação das formas amastigotas, ou promastigotas utilizando geralmente aspirado de lesões, raspado das bordas das lesões ou esfregaços (“imprinting”) de biópsia.

Entretanto, esses métodos de observação direta do parasito apresentam sensibilidade baixa (Gontijo e Melo, 2004; Sundar et al., 2002; Srividya et al., 2012). No caso do exame citológico é frequente a ocorrência de infecções secundárias nas lesões, o que atrapalha a detecção das formas amastigotas. Além disso, às vezes as amostras apresentam baixa densidade parasitária, dessa forma, o resultado irá depender do investigador e da técnica utilizada. No caso da cultura, a sensibilidade depende do tipo de meio utilizado, da quantidade de material depositado no tubo e da espécie do parasito. Além disso, o inconveniente das culturas são as frequentes contaminações por fungos e bactérias. O crescimento em cultura da maioria das espécies de Leishmania ocorre após uma a duas semanas, recomendando-se que as culturas sejam examinadas por no mínimo 4 semanas. Assim, o diagnóstico pode ser bem demorado (Berman, 1997; Ferreira e Ávila, 2001).

Outra variável não utilizada em rotina é o isolamento e cultivo in vivo do parasito, em hamsters, ou camundongos isogênicos (principalmente da linhagem BALB/c) (Ferreira e Ávila, 2001). 


\subsubsection{Diagnóstico imunológico da LVC.}

Em animais com LVC a soroconversão ocorre aproximadamente 3 meses após a infecção. Os métodos sorológicos mais utilizados são: Imunofluorescência Indireta (IFI), Ensaio Imunoenzimático (ELISA) e Aglutinação Direta (AD). Apesar da LVC no Brasil estar associada habitualmente à L. (L.) infantum- chagasi, não se utiliza um antígeno específico dessa espécie em testes convencionais (Romero et al., 2009). Não existe um consenso quanto ao emprego do antígeno, e diferentes espécies de Leishmania são utilizadas como fonte de antígenos. (Borges et al., 2001).

No Brasil, inquéritos sorológicos para a identificação de cães infectados com LVC são realizados com testes comerciais. Os mais utilizados são os testes de IFI e ou ELISA produzidos pelo Instituto Bio-Manguinhos da Fundação Oswaldo Cruz no Rio de Janeiro, que utilizam como antígeno extrato total de formas promastigotas de Leishmania major-like. Esses testes são empregados pelo Ministério da Saúde e baseiam-se exclusivamente na detecção de anticorpos não avaliando a carga parasitária. A IFI tem especificidade baixa nos períodos iniciais da doença, e podem ocorrer reações cruzadas com tripanossomíases, malária, esquistossomose, oncocercose, e algumas micoses sistêmicas (Garcia, 2001; Rey, 2002). O método de ELISA é o mais utilizado, principalmente por ser mais rápido e econômico, além de ser um método simples e possível de se realizar com apenas $50 \mu \mathrm{l}$ de sangue. A sensibilidade do teste é de 98\%, mas pode ocorrer reação cruzada com $T$. cruzi, principalmente com preparados antigênicos totais (Ferreira et al., 2007; Maia e Campino, 2008). 


\subsubsection{Diagnóstico molecular - PCR para LVC.}

Nos últimos anos, vários ensaios de PCR vêm sendo desenvolvidos e utilizados no diagnóstico das Leishmanioses. Cada ensaio utiliza uma abordagem diferente (PCR convencional, Nested-PCR, PCR em tempo real) visando diferentes sequências do genoma da Leishmania (Reithinger and Dujardin, 2007).

Diferentes sequências do genoma de Leishmania spp. vêm sendo usadas pelos pesquisadores com iniciadores nessas reações de amplificação, e vários estudos têm demonstrado a importância da técnica de PCR no diagnóstico etiológico das leishmanioses (Marques et al., 2001; Zhang et al., 2006), como a que utiliza iniciadores direcionados para o gene que codifica a enzima G6PDH (Castilho et al., 2003, 2008); o gene de mini-exon transcritos do rDNA- ITS1 (Marfurt et al., 2003; Schonian et al., 2003); ou o gene que codifica a proteína de choque térmico hsp70 (Weirather et al., 2011; Montalvo et al., 2010; Garcia et al., 2004).

Com relação ao diagnóstico parasitológico molecular da LV nas Américas, destacamos ainda o uso da PCR direcionada ao kDNA (DNA de cinetoplato) uma molécula que contém aproximadamente 10.000 minicírculos naturalmente amplificados, permitindo uma melhor sensibilidade da técnica (Weirather et al., 2011; Floeter-Winter e Shaw, 2004).

Utilizando essa abordagem tem-se conseguido detectar DNA de Leishmania em uma grande variedade de amostras que incluem: biópsias de lesões, "imprinting", exsudatos, aspirados de linfonodo, medula óssea, baço, sangue total, creme leucocitário ou soro (Singh, 2006; Reithinger et al., 2007). 
O diagnóstico correto e a identificação da espécie de Leishmania envolvida na infecção é uma das prioridades de estudos sobre Leishmaniose no momento. $O$ diagnóstico específico auxilia na avaliação correta da espécie do parasito envolvida na infecção, permitindo um tratamento mais adequado. Dessa forma, propusemos neste estudo uma análise comparativa das principais técnicas de diagnóstico utilizadas atualmente para a LVC. Para isto, avaliamos a sensibilidade e especificidade dessas técnicas frente a diferentes tecidos coletados de cães sorologicamente positivos da cidade de Embu das Artes São Paulo, Brasil. 


\section{JUSTIFICATIVA}

Considerando que os métodos mais utilizados na identificação da Leishmaniose Visceral Canina (LVC) apresentam baixa sensibilidade e/ou especificidade. Um dos maiores desafios relacionados com o diagnóstico dessa doença é a dificuldade em se obter um teste diagnóstico confiável, que seja capaz de identificar a presença do parasito, e que ao mesmo tempo, consiga indicar qual a espécie de Leishmania está envolvida na infecção.

Atualmente a diversidade de espécies de Leishmania é considerada como um dos fatores determinantes na manifestação clinica das Leishmanioses. Portanto, a determinação, de um teste diagnóstico confiável e eficiente se torna necessário e imprescindível para diagnosticar, tratar e auxiliar no controle e prevenção de novos casos da doença.

Tendo em vista que a sensibilidade e especificidade das técnicas de PCR diminuem significantemente quando se utiliza amostras clínicas. O objetivo deste trabalho é propor uma análise comparativa entre os principais testes parasitológicos utilizados em laboratório (parasitológico direto e isolamento do parasito em cultura in vitro) com a Reação em Cadeia da Polimerase (PCR), utilizando diferentes tecidos de cães soropositivos para LVC.

A utilização de diferentes abordagens técnicas com diferentes tecidos não é novidade na literatura (Marques et al., 2001; Castilho et al., 2003; Garcia et al., 2004; 
Zhang et al., 2006). Entretanto, nenhum trabalho descreve uma técnica capaz de identificar especificamente o agente etiológico com possibilidade de aplicação viável no programa de controle da LVC, muito menos que proponha a padronização de métodos moleculares levando em consideração a natureza do material clínico. Além disso, dados de um inquérito sorológico realizado em 2002 revelaram a presença de cães com sorologia positiva para Leishmaniose na cidade de Embu das Artes, que está localizada a apenas $23 \mathrm{~km}$ da cidade de São Paulo.

Portanto, acreditamos que esses resultados podem contribuir significantemente para melhorar as técnicas diagnósticas e auxiliar no tratamento, prevenção, controle e estudos futuros relacionados à LVC ao redor do mundo. 


\section{OBJETIVOS:}

\subsection{Objetivo Geral}

Avaliar a sensibilidade da PCR (com iniciadores dirigidos ao kDNA, e ao gene da $h s p 70)$ utilizando diferentes amostras de tecidos coletadas de cães soropositivos para o diagnóstico da Leishmaniose Visceral Canina (LVC) do município de Embu das Artes - SP; comparando os resultados obtidos pelos diferentes métodos diagnósticos avaliados: PCR; testes parasitológicos, exame direto e cultura in vitro; sorológico (ELISA); além dos dados clínicos obtidos.

\subsection{Objetivos Específicos.}

a) Realizar testes parasitológicos diretos em diferentes amostras de tecidos de cães provenientes do município de Embu das Artes - SP;

b) Avaliar qual o melhor material para uma maior eficiência no diagnóstico parasitológico e molecular da LVC;

c) Comparar os resultados obtidos com os diferentes tecidos analisados por cada um dos testes realizados;

d) Identificar a espécie de Leishmania envolvida na infecção autóctone canina na cidade de Embu das Artes - SP. 
Martins TFC

\section{MATERIAIS E MÉTODOS}

\subsection{Inquérito sorológico realizado na cidade de Embu das Artes; Coleta das amostras de tecido; Acompanhamento clínico da população em risco:}

\subsubsection{Inquérito sorológico:}

Após suspeita de casos de Leishmaniose Visceral Canina (LVC) nas proximidades da cidade de São Paulo, um inquérito sorológico com busca ativa de cães positivos para LVC foi realizado por iniciativa da Secretaria da Saúde e do Centro de Controle de Zoonoses (CCZ) da cidade de Embu das Artes - SP. O período oficial do inquérito sorológico foi de novembro de 2006 a março de 2009, com o apoio da Superintendência de Controle e Endemias Nacionais (SUCEN) que realizou a captura periódica de flebotomíneos para posterior análise da fauna vetorial da região.

Durante este período, médicos veterinários e profissionais da saúde realizavam, uma vez por semana de cada mês, testes sorológicos para a LVC utilizando o kit de Biomanguinhos fornecido pelo laboratório do Instituto Adolfo Lutz de São Paulo. Inicialmente o inquérito ficou restrito a bairros localizados na região oeste da Rodovia Régis Bittencourt, como: Ressaca, Capuava, Maranhão, Itatuba, Chácara Bartira e o Centro da Cidade de Embu das Artes. Ao final do inquérito foram realizados testes sorológicos em 2348 cães com 66 cães apresentando sorologia positiva para LVC. 


\subsubsection{Coleta das amostras de tecidos dos cães:}

Dos 66 cães que apresentaram sorologia positiva apenas 26 cães foram encontrados vivos no local cadastrado na triagem inicial do inquérito. Os cães foram transferidos para Serviço de Vigilância Epidemiológica (SVE) do município para avaliação clínica dos médicos veterinários. Após o consentimento dos proprietários todos os 26 cães foram anestesiados com tiopental sódico $1 \mathrm{~g}$ Cristália $(25 \mathrm{mg} / \mathrm{kg})$ e posteriormente eutanasiados com injeção intravenosa de cloreto de potássio 19,1\%, como recomenda o Manual de Vigilância e Controle da Leishmaniose Visceral (Ministério da Saúde, 2006). Após a eutanásia, uma série de amostras de sangue e tecidos de cada cão infectado foi coletada pelo nosso grupo de acordo com um protocolo desenvolvido em nosso laboratório.

Para a coleta do sangue utilizamos: 2 tubos secos para a coleta de soro e 1 tubo com K2EDTA (7,2 mg) para coleta de sangue total, mantido em gelo para preservação da amostra. O procedimento para coleta de tecido envolvia: 4 micros tubos contendo: $100 \mathrm{UI}$ de penicilina, $100 \mu \mathrm{g}$ de estreptomicina e $50 \mu \mathrm{g}$ de fluocitosina. Foi coletado de cada cão amostras de tecidos de baço, pele com lesão (incluindo feridas provenientes de mordidas e arranhões, no caso dos cães assintomáticos), pele sem lesão e aspirado de linfonodo poplíteo. Cada amostra de tecido foi dividida em quatro partes para a realização dos testes parasitológicos propostos: 1) para a cultura e isolamento do parasito (cultura in vitro); 2) para a realização da pesquisa do parasito em Teste Direto de "imprinting" (impressões feitas em lâminas dos tecidos de necropsia) corados com Giemsa; 3) para Teste Direto (estudo histológico corado por 
Martins TFC

Hematoxilina-Eosina - HE); e 4) para extração do DNA genômico e posterior reação de amplificação por PCR.

Como controle negativo foram coletadas amostras de pele sem lesão (pequeno fragmento de pele coletado após castração) e sangue de 28 cães das mesmas regiões da cidade de Embu das Artes descritas acima, sem sintomas clínicos da doença e com sorologia negativa para LVC. Vale ressaltar que, obviamente, não foram coletadas amostras dos demais tecidos dos cães normais por aspectos éticos. O presente projeto foi aprovado pela Comissão de Pesquisa e Ética (CPE) e a Comissão de Ética no Uso de animais em Pesquisa (CEUA) do Instituto de Medicina Tropical (IMT) sob o número 2011/104 em 29 de fevereiro de 2012 (Anexo 2).

\subsubsection{Investigação de casos clínicos da população humana em risco:}

Preocupados com a incidência da LVC na cidade de Embu das Artes, o Dr. Ângelo Lindoso (colaborador do projeto) em parceria com a Unidade Básica de Saúde (UBS) da região de Embu das Artes, acompanhou 184 crianças entre 4 e 10 anos de idade durante dois anos (2009 e 2010), residentes da mesma região de transmissão

autóctone da doença canina. Foram realizadas avaliações clínicas periódicas (uma vez por mês) para verificar clinicamente se alguma criança apresentava suspeita de LV. 


\section{2. $\quad$ Teste de Cultura de parasitos in vitro.}

Os testes de cultura in vitro, apesar de apresentarem baixa sensibilidade e de serem demorados para a obtenção do resultado final, são fundamentais para o isolamento do parasito envolvido na infecção (de Almeida et al., 2011; Chargui et al., 2011). Assim, para a realização dos testes de cultura in vitro com a possibilidade de posterior isolamento dos parasitos presentes nos tecidos dos cães analisados, os fragmentos de biópsias foram macerados e cultivados em meio 199 com sais de Hanks (Invitrogen), acrescido de $10 \%$ de soro fetal bovino; $2 \%$ de urina humana (Allahverdiyev et al., 2011); adenina $100 \mu \mathrm{M}$; HEPES $40 \mathrm{mM}(\mathrm{pH}$ 7,4); hemina 10 $\mu \mathrm{g} / \mathrm{mL}$; penicilina $50 \mathrm{U} / \mathrm{mL}$; estreptomicina $50 \mu \mathrm{g} / \mathrm{mL}$; e biotina $4 \mu \mathrm{M}$, esterilizado por filtração. Em seguida, a suspensão foi transferida para um frasco de cultura e incubada em estufa B.O.D à 26ำ C. Foram realizadas leituras diárias das culturas em microscópio invertido e as culturas positivas foram repicadas e expandidas para posterior extração do DNA e isolamento do parasito, onde as células foram transferidas para um novo meio de cultura celular 199 , acrescido de $20 \%$ de soro fetal bovino; $2 \%$ de urina humana e DMSO, e em seguida armazenadas em nitrogênio líquido.

Para padronização, controle e referência dos experimentos utilizamos as seguintes culturas de espécies dos parasitos, gentilmente cedidas pelo Prof. Dr. J.J. Shaw do ICB-USP: Leishmania (Leishmania) infantum-chagasi (MCER/BR/1918/M6445), L. (L.) amazonensis (MHOM/ BR/ 1973 / M2269) e L. (Viannia) braziliensis (MHOM/BR/1975/M2903). 


\subsection{Teste Direto - Estudo histológico por HE e Giemsa.}

Para a pesquisa direta foi utilizado: 1) analise de "imprinting" corados por Giemsa; 2) analise de cortes histológicos corados com HE.

No primeiro procedimento foi feita a fixação dos "imprinting" com 15 a 20 gotas de metanol incubado a temperatura ambiente (TA) por 5 minutos, em seguida as lâminas foram lavadas com água e colocadas para secar em TA. O corante de Giemsa foi diluído para a solução de uso (3 gotas em $2 \mathrm{~mL}$ de água tamponada pH 7,2), em seguida foi adicionado por toda a extensão da lâmina por 20 minutos; após este período as lâminas eram lavadas com água tamponada.

No segundo procedimento os fragmentos foram direcionados para o estudo histológico, onde ocorreu a fixação dos tecidos em soluções de formalina tamponada a $10 \%$ e pH 7,4 por 48 horas, em seguida os fragmentos foram processados segundo as técnicas de rotina para inclusão em parafina.

Para um melhor desempenho nós utilizamos a metodologia de avaliação da lâmina utilizada em leitura de esfregaço sanguíneo, ou seja, percorríamos todo o campo da lâmina em "zig zag" observando presença de formas amastigotas. 
Martins TFC

\subsection{Extração de DNA das amostras analisadas.}

\subsubsection{Extração do DNA de cultura de promastigota:}

A extração de DNA genômico de cultura de formas promastigotas de Leishmania foi realizada segundo protocolo do Kit de Extração de DNA ('Real Genomics DNA Extraction Kit', RBC). Partindo de $1 \times 10^{7}$ células por $\mathrm{mL}$, centrifugação inicial de $8000 \mathrm{rpm}$ por $20 \mathrm{seg}$. Adicionamos ao precipitado $150 \mu \mathrm{L}$ do RBC "Lysis Buffer". Após a lise celular e agitação em vortex, as amostras foram incubadas a $70^{\circ} \mathrm{C}$, 10 min. Numa segunda etapa foi realizada uma desproteinização e separação dos ácidos nucléicos com adição de $200 \mu \mathrm{L}$ de etanol (96\%-100\%). Imediatamente após esta adição as amostras foram agitadas em vortex, por 10seg. O sistema de coluna GD (provido pelo kit de extração) foi montado, e a suspensão adicionada no centro da coluna GD. Todo o sistema foi centrifugado a 13000 rpm por 2 min, em seguida adiciona-se $200 \mu \mathrm{L}$ do tampão W1 na coluna, seguido de mais uma centrifugação de aproximadamente $30 \mathrm{seg}$ a $13000 \mathrm{rpm}$. Adicionamos $600 \mu \mathrm{L}$ do Wash Buffer, seguida de mais uma centrifugação de 13000 rpm por 30seg, para mais uma lavagem do DNA. Descartamos o filtrado, e realizamos uma nova centrifugação de 13000 rpm por 3 min, para secar a coluna. Para eluição do DNA a coluna GD foi transferida para um tubo de 1,5 mL limpo, onde adicionamos $100 \mu \mathrm{L}$ do Tampão de Eluição no centro da coluna, seguido de incubação à temperatura ambiente por 5 min, e de uma nova centrifugação de 13000 rpm por 30 seg. A solução contendo o DNA purificado foi armazenada em freezer a $-20^{\circ} \mathrm{C}$. 


\subsubsection{Extração do DNA das biopsias de tecidos:}

A extração do DNA a partir das biópsias de tecido coletado foi realizada segundo a metodologia indicada pelo protocolo de extração de tecido animal do Kit de Extração de DNA ('Real Genomics DNA Extraction Kit', RBC). Utilizamos cerca de 20 mg de cada amostra, que foi macerada com a ajuda de um pistão de maceração em presença de $200 \mu \mathrm{L}$ de tampão GT. Para a lise das proteínas e o rompimento celular adicionamos $20 \mu \mathrm{L}$ de proteinase $\mathrm{K}(10 \mathrm{mg} / \mathrm{mL})$ incubado à $60^{\circ} \mathrm{C}$ por $30 \mathrm{~min}$, passada esta primeira incubação adicionamos $200 \mu \mathrm{L}$ de tampão GB e uma nova incubação foi feita à $70^{\circ} \mathrm{C}$ por $20 \mathrm{~min}$.

Adicionamos ao lisado $200 \mu \mathrm{L}$ de etanol (96-100\%). O DNA foi separado pelo sistema de coluna GD, no qual o lisado foi submetido a uma centrifugação de 1300 rpm 2 min, para o DNA aderir à coluna. Desta forma seguimos para a sequência de lavagem do DNA, onde adicionamos $400 \mu \mathrm{L}$ de tampão W1 na coluna, centrifugamos a 13000 rpm por 30seg, descartamos o filtrado e adicionamos $600 \mu \mathrm{L}$ do tampão W2. Nova centrifugação de 13000 rpm por 30 seg foi realizada para remover o excesso de solução, e finalmente adicionamos o Tampão de Eluição pré-aquecido à $70^{\circ} \mathrm{C}$, seguido por uma incubação de 5 min a TA, e centrifugação do sistema de coluna à 13000rpm por 30 seg. A solução contendo o DNA purificado foi armazenada em freezer a $-20^{\circ} \mathrm{C}$. 


\subsubsection{Extração do DNA de sangue:}

A extração de DNA de sangue segue as etapas do protocolo de extração de DNA de sangue total fresco do Kit de Extração de DNA ('Real Genomics DNA Extraction Kit', RBC). Foi adicionado $300 \mu \mathrm{L}$ das amostras, em um tubo de 1,5 mL, e em seguida adicionamos $900 \mu$ de RBC "Lysis Buffer" para promover a lise celular. Após agitação em vortex, cada amostra foi incubada por $5 \mathrm{~min}$ a TA, seguida de 2 min de centrifugação a $3000 \mathrm{rpm}$. Descartamos sobrenadante, e ressuspendemos o precipitado em $100 \mu \mathrm{L}$ de RBC "Lysis Buffer". Em seguida, adicionamos $200 \mu \mathrm{L}$ de GB Buffer com uma leve agitação manual, posteriormente, incubamos a TA por 10 min até a clarificação do lisado celular. Após a incubação, adicionamos $200 \mu \mathrm{L}$ de etanol (96$100 \%$ ) e após montar o sistema de coluna GD, adicionamos toda a suspensão ao sistema, prosseguindo com uma centrifugação de 13000 rpm por 5min, para o DNA se ligar à coluna. Após essa etapa, adicionamos $400 \mu \mathrm{L}$ de W1 Buffer, centrifugamos a $13000 \mathrm{rpm}$ por $30 \mathrm{seg}$ e descartamos o filtrado. O sistema foi centrifugado por mais 3 min para secagem. Finalmente, adicionamos $50 \mu \mathrm{L}$ de Tampão de Eluição préaquecido, incubamos por 5 min a temperatura ambiente, seguido de 30 seg de centrifugação de 13000 rpm para eluição, obtenção e armazenamento da solução contendo o DNA extraído. 


\subsection{Padronização da técnica de amplificação de DNA por PCR.}

As concentrações de DNAs presente nas soluções extraídas de cultura, tecidos e sangue foram determinadas em aparelho de espectrofotometria NanoDrop ND-1000 spectrophotometer (NanoDrop Technologies Inc.). As concentrações de DNA utilizadas nas reações de PCR convencional foram todas de $50 \mathrm{ng} / \mu \mathrm{L}$.

Para padronizar a reação em cadeia da polimerase (PCR) e verificarmos a existência do DNA da Leishmania, nós utilizamos iniciadores voltados para a região conservada do cinetoplasto do parasito (kDNA) (Degrave et. al., 1994), e para a região do gene que codifica a proteína de choque térmico hsp70 (Garcia et al., 2004). Desta forma nós verificamos na literatura pares de iniciadores que poderiam compreender estas regiões (Volpini et al. 2004; Andrade et al., 2006; Medeiros et al., 2008, Montalvo et al., 2012).

Após verificarmos a sequencia de nucleotídeos na literatura, nós submetemos as sequencias ao programa BLAST, para conferir quais os organismos que estes iniciadores poderiam parear. Após confirmarmos que estes iniciadores eram específicos para as espécies de Leishmania, sintetizamos os iniciadores para as reações de PCR com alvos para o kDNA e o gene hsp70: KDNA-20 (Foward) 5' GGG (G/T) AGGGGCGTTCT (G/C) CGAA 3', o iniciador kDNA-22 (Reverse) 5' (G/C) (G/C) (G/C) (A/T) CTAT (A/T) TTACACCAACCCC 3'; PCR-hsp70 N-F (Foward) 5' GGACGCCGGCACGATTKCT 3'; e o iniciador PCR-hsp70 N-R (Reverse) 5' CGAAGAAGTCCGATACGAGGGA 3'. De acordo com o trabalho do grupo de pesquisa de Volpini (2004) e Degrave (1994) para a kDNA-PCR, e Montalvo (2012) para a 
Martins TFC

hsp70-PCR, estes iniciadores amplificam um fragmento de DNA de 120 pares de base (pb) (kDNA-PCR), e 593 pares de base (hsp70-PCR) respectivamente.

Os reagentes utilizados para reação de PCR (Mix de PCR) foram: Taq polimerase (5 U/ $\mu \mathrm{L})$, tampão de reação1X (KCl 50mM, Tris- $\mathrm{HCl} 10 \mathrm{mM} \mathrm{pH=8,8),} \mathrm{MgCl2}$ (25 mM), dNTPs (10mM) (dATP, dCTP, dGTP e dTTP), os iniciadores em uma concentração de 10 pM correspondendo ao alvo desejado e o DNA das amostras na concentração de $50 \mathrm{ng} / \mu \mathrm{L}$. As reações de PCR foram padronizadas para um volume final de $25 \mu \mathrm{L}$, e todas as soluções foram realizadas em Workstation próprias para PCR padrão DNA free.

As condições para a amplificação foram padronizadas em um termociclador programável (Applied Biosystems Veriti ${ }^{\mathrm{TM}}$ Thermal Cycler), onde foi determinado as seguintes condições: $94^{\circ} \mathrm{C}$ por 4 minutos, seguido por uma quantidade de 35 ciclos de 94ํㅡ por 1 minuto para a desnaturação do DNA; 58ㅇ (para kDNA primers) e $60^{\circ} \mathrm{C}$ (para hsp70 primers), ambos por 1 minuto para o anelamento; e $72^{\circ} \mathrm{C}$ por 30 segundos para a extensão, e finalizando em $72^{\circ} \mathrm{C}$ por $5 \mathrm{~min}$.

Para um controle da reação de PCR, assim como da extração de DNA, nós utilizamos iniciadores voltados para o gene que codifica uma proteína estrutural de membrana celular a beta-Actina. Assim, verificamos na literatura uma sequencia de nucleotídeos correspondentes a essa região em cães (Peleg et al., 2009), em seguida verificamos a sequencia no programa BLAST como descrito anteriormente.

Desta forma também foi sintetizado o par de iniciadores denominado Actin-R 5'GCG CAA GTA CTC TGT GTG GAT3' e Actin-F 5'GTC GTA CTC CTG CTT GCT GAT3'. As reações de amplificação também foram padronizadas no termociclador 
programável (Applied Biosystems Veriti ${ }^{\mathrm{TM}}$ Thermal Cycler), onde determinamos as seguintes condições: $95^{\circ} \mathrm{C}$ por 5 minutos, seguido por 35 ciclos de $93^{\circ} \mathrm{C}$ por 1 min na desnaturação; $61^{\circ} \mathrm{C}$ por 1 minutos para o anelamento; $72^{\circ} \mathrm{C}$ por 30 segundos para a extensão, e finalizando com $72^{\circ} \mathrm{C}$ por $7 \mathrm{~min}$.

Para as padronizações das reações de PCR foi utilizado o DNA genômico extraído das espécies controles citadas no item 4.2 como controle positivo para os iniciadores dirigidos ao kDNA, e uma amostra de DNA proveniente do tecido do baço do primeiro cão eutanasiado, também utilizada como controle positivo para a reação dos iniciadores dirigidos a beta-actina.

Após a reação de PCR, o produto amplificado foi submetido à corrida eletroforética em gel de agarose $2 \%$ com 80 volts (V) por 40 minutos. Para visualizar o resultado das amplificações do DNA, utilizamos uma solução contendo brometo de etídio $(0,5 \mathrm{mg} / \mathrm{mL})$, um intercalante de DNA que ao entrar em contato com a luz ultravioleta (UV) permite a visualização do produto de DNA amplificado. Cada reação de amplificação teve como controle negativo, um tubo contendo todos os reagentes utilizados na reação de PCR menos o DNA da amostra canina; e um controle positivo contendo todos os reagentes e o DNA genômico extraído da cultura de uma espécie de Leishmania conhecida. 


\subsection{Digestão enzimática do produto de DNA amplificado por PCR visando à identificação da espécie do parasito.}

Após os resultados de amplificação das PCRs com os iniciadores dirigidos ao kDNA, as amostras foram submetidas a digestão enzimática com a enzima de restrição Hae III FastDigest (BsuRI- Fermentas), e submetidas ao próprio protocolo FastDigest da Fermentas Life Sciences, onde utilizamos $5 \mu \mathrm{L}$ do produto de amplificação para um volume final de $20 \mu \mathrm{L}$ do Mix de PCR-RFLP à temperatura de $37^{\circ} \mathrm{C}$ por um período de 30 min. Quanto a amplificação com os iniciadores dirigidos ao hsp70, as amostras foram submetidas a digestão enzimática com a enzima de restrição BsaJl e em seguida com a enzima EcoRII (FastDigest) da Fermentas, também foram submetidas ao próprio protocolo da Fermentas Life Sciences. As enzimas foram escolhidas de acordo com os resultados apresentados para a diferenciação das espécies de Leishmania pelo grupo de Volpini (2004) e Montalvo (2012) respectivamente.

Todas as reações foram padronizadas com a utilização de controles negativos, onde utilizávamos todos os reagentes do Mix de PCR-RFLP menos a amostra de DNA amplificado, e um controle positivo da digestão enzimática, onde utilizamos o DNA amplificado após ser extraído das espécies de Leishmania conhecidas (Leishmania (L.) chagasi (MCER/BR/1918/M6445), L. (L.) amazonensis (MHOM/ BR/ 1973 / M2269), e L. (V.) braziliensis (MHOM/BR/1975/M2903) com indica o item 4.4.1).

Após o tempo de digestão enzimática, os produtos foram submetidos à corrida eletroforética em gel de poliacrilamida 10\%, a 60 volts por 2 horas, em tampão de corrida TAE 1X (Tris-acetado EDTA). 


\subsection{Padronização da técnica de PCR em tempo real:}

As reações de PCR em tempo real foram realizadas em triplicata no equipamento ABI 7500 Real-Time PCR System (Applied Biosystems), utilizando o sistema QuantFast SYBR Green PCR (QIAgen) com iniciadores dirigidos ao gene que

codifica a proteína de choque térmico hsp70 (PCR N-F 5' GGACGCCGGCACGATTKCT 3' e PCR N-R 5' CGAAGAAGTCCGATACGAGGGA 3'.

As reações de PCR em tempo real foram realizadas com volume final de $25 \mu \mathrm{L}$ de acordo com o protocolo do Sistema QuantFast SYBR Green PCR Master Mix da QIAgen. O Mix da reação continha a enzima Hot Start Taq Plus DNA, QuantiFast SYBR Green Buffer, dNTP mix e SYBR Green, os iniciadores (5' GGACGCCGGCACGATTKCT 3' e 5' CGAAGAAGTCCGATACGAGGGA 3') na concentração de 5 pM, água RNAse-Free (QIAgen) e 40 ng de DNA genômico extraído das amostras de baço, linfonodo, pele com e sem lesão, e sangue dos cães soropositivos para LVC.

Para cada lote de amostra testada foi construída uma curva padrão dos controles positivos contendo o DNA de Leishmania infantum-chagasi nas seguintes concentrações: $10^{8}, 10^{7}, 10^{6}, 10^{5}, 10^{4}, 10^{3}, 10^{2}, 10$ parasitos $/ \mathrm{mL}$, e dois controles negativos. Em um dos controles negativos utilizamos o DNA proveniente de cães sabidamente negativos para LV, e no outro controle negativo utilizamos apenas água ultra pura.

A reação de PCR em tempo real seguiu as seguintes etapas: 95ํㅡ $\mathrm{C}$ por 10 minutos, 95 $\mathrm{C}$ por 15 segundos, 60 $\mathrm{C}$ por 1 minuto durante 40 ciclos. Com o intuito de 
Martins TFC

avaliar o padrão de dissociação da dupla fita de DNA, nós também realizamos a curva da Temperatura de Melting, que começava na temperatura de $60^{\circ} \mathrm{C}$ até $95^{\circ} \mathrm{C}$ (completa dissociação da dupla fita), aquecendo $1^{\circ} \mathrm{C}$ a cada minuto.

\subsection{Sequenciamento das amostras de produtos de PCR:}

As amostras de produtos de PCR que apresentaram resultados discordantes entre os resultados da PCR com iniciadores dirigidos ao kDNA dos diferentes tecidos dos cães soropositivos, foram sequenciadas no Centro de Estudos do Genoma Humano da USP.

Inicialmente as amostras foram purificadas utilizando o Kit de purificação de produtos de PCR da Invitek - Invisorb Fragment CleanUP. As amostras foram encaminhadas para o Centro de estudos do Genoma Humano nas seguintes condições: 1 tubo de 0,2 mL contendo $5 \mu \mathrm{L}$ da amostra TF-1 (na concentração de 10 $\mathrm{ng} / \mu \mathrm{L}$ ) acrescidos de $2,5 \mu \mathrm{L}$ do respectivo primer a $5 \mu \mathrm{M}$ (total: $7,5 \mu \mathrm{L}$ ).

Todas as amostras foram sequenciadas no aparelho da Applied Biosistem ABI 3730 DNA Analyzer, todas as reações foram feitas utilizando o reagente BigDye ®Terminator v3.1 Cycle sequencing Kit. A análise das sequencias de DNA foram realizadas pelo software Sequencing Analysis 5.3.1 utilizando o Base Caller KB. 


\subsection{Análise estatística:}

A análise estatística foi realizada utilizando o programa SigmaStat 3.5 (Systat Software Inc., 2006). Os níveis de significância dos testes foram fixados aceitando um erro tipo 1 de $5 \%(\alpha=0,05)$.

Os testes estatísticos foram empregados para analisar os resultados obtidos pelos seguintes métodos:

-Pesquisa direta do parasito em lâminas coradas com Giemsa e HE;

-Teste de cultura in vitro;

-PCR convencional com iniciadores para o kDNA;

-PCR convencional com iniciadores para o hsp70.

\subsubsection{Teste Chi-quadrado $\left(\chi^{2}\right)$ :}

O teste $\chi^{2}$ foi utilizado para avaliar a existência de associação entre as diferentes técnicas estudadas empregando diferentes tecidos coletados de cães que apresentavam sorologia positiva no momento da coleta.

Inicialmente, foi avaliada a associação entre cada técnica diagnóstica (pesquisa direta do parasito em lâminas coradas, teste de cultura in vitro do parasito, kDNA-PCR e hsp70-PCR) e os diferentes tecidos biopsiados e examinados (baço, linfonodo, pele sem lesão e pele com lesão). O objetivo dessa análise foi verificar se existe diferença significante no diagnóstico da LVC quando se utilizam diferentes amostras de tecidos, analisando cada uma das técnicas citadas a cima, separadamente. Ou seja, qual é o melhor tecido para ser empregado em cada técnica. 
Em seguida, foi avaliada a associação entre cada tecido e as técnicas diagnósticas. O objetivo dessa análise foi verificar se existe diferença significante no diagnóstico da LVC quando se utilizam diferentes técnicas, analisando cada um dos tecidos, separadamente. Ou seja, qual é a melhor técnica quando se emprega determinado tecido.

As análises seguintes foram realizadas considerando as técnicas parasitológicas diretas (pesquisa direta do parasito em lâminas coradas e cultura do parasito em meio de cultura in vitro) em conjunto. A definição do diagnóstico de cada cão foi feita individualmente. Deste modo, se um cão era positivo em qualquer uma das técnicas parasitológicas, o cão foi considerado positivo. O mesmo critério determinava resultados negativos e inconclusivos. Desta forma, foi avaliada a associação entre cada tecido e as técnicas parasitológicas e moleculares (kDNA-PCR e hsp70-PCR) em conjunto e separadamente. O objetivo dessa análise foi verificar se existe diferença significante no diagnóstico da LVC utilizando métodos parasitológicos ou moleculares, analisando cada um dos tecidos, separadamente.

\subsubsection{Teste de McNemar:}

O teste de McNemar foi utilizado para comparar os métodos diagnósticos estudados empregando amostras pareadas.

Nas amostras com sorologia positiva e negativa, foi avaliada a existência de associação marginal entre os métodos moleculares (kDNA-PCR e hsp70-PCR) nos tecidos pele sem lesão e sangue total. Nessas amostras, a concordância entre os

resultados das técnicas foi avaliada através do Índice Kappa (к) de Cohen e o respectivo intervalo com $95 \%$ de confiança. 
Martins TFC

As análises seguintes foram realizadas considerando "padrão ouro" os métodos parasitológicos diretos (pesquisa direta do parasito em lâminas coradas e cultura do parasito em meio de cultura in vitro) em conjunto, como descrito no item 4.9.1.

Com o parasitológico como "padrão ouro", foram calculadas a sensibilidade e especificidade dos métodos moleculares em cada tecido estudado. Também se compararam os métodos dois a dois (kDNA-PCR $X$ hsp70-PCR, kDNA-PCR $X$ parasitológico e hsp70-PCR X parasitológico) em cada um dos tecidos estudados. Desta forma, analisamos se existia diferença entre os métodos moleculares e parasitológicos em cada tecido empregado.

\subsubsection{Teste exato de Fisher:}

O teste exato de Fisher foi utilizado para avaliar a uniformidade da amostragem de cães com sorologia positiva (grupo positivo) e negativa (grupo controle) em relação a associação entre kDNA-PCR e cada tecido (pele sem lesão e sangue total) obtido de cães com sorologia negativa. 


\section{RESULTADOS}

\subsection{Inquérito sorológico realizado em Embu das Artes; Avaliação clínica dos cães; Coleta das amostras de tecido.}

Os testes sorológicos realizados no inquérito da pesquisa de LVC por iniciativa da Secretaria da Saúde e do Centro de Controle de Zoonoses (CCZ) de Embu das Artes - SP revelaram que dos 2348 cães analisados, 66 (2,81\%) apresentaram sorologia positiva para LVC.

Após o resultado dos testes sorológicos, a equipe de profissionais do CCZ entrou em contato com os donos dos cães com sorologia positiva, para que estes passassem por médicos veterinários especializados e realizassem os exames clínicos nos cães. Porém, a equipe de profissionais só encontrou 26 dos 66 cães positivos, que foram submetidos à avaliação clínica pelo CCZ de Embu das Artes e posteriormente eutanasiados.

Após a eutanásia, uma série de amostras de sangue e de diferentes tecidos (baço, pele com lesão, pele sem lesão e aspirado de linfonodo) foi coletada de cada cão, de acordo com o protocolo desenvolvido pelo nosso laboratório e descrito no item 4.1. de materiais e métodos. Desta forma, foram analisadas amostras de 4 tecidos diferentes de cada um dos 26 cães eutanasiados (perfazendo um total de 104 amostras) que foram submetidas a 3 testes diagnósticos diferentes (cultura in vitro, parasitológico direto [HE e Giemsa], e PCR [utilizando dois iniciadores diferentes]). 
De acordo com as descrições dos sinais clínicos encontrados pelos veterinários, os 26 cães foram separados em três grupos (Tabela 1): 1) sintomáticos: cães com pelo menos um sinal característico de LVC, determinado como: linfadenopatia, dermatites esfoliativas, ulcerações na pele, lesões oculares, hepatoesplenomegalia, perda de peso ou onicogrifose, encontrando um total de 17 dos 26 eutanasiados; 2) oligossintomáticos: cães que apresentavam sinal ou sintomas sugestivos, mas não característicos de LVC como pequena perda de peso e pelo opaco, encontrando 6 cães com essa característica; e 3) assintomáticos: cães que não apresentavam nenhuma alteração ou sinal clínico da doença, encontrando 3 cães nessas condições.

Tabela 1- Classificação clínica dos cães

\begin{tabular}{cc|c|c}
\hline & Cães & $\mathbf{N}^{\circ}$ & $(\%)$ \\
\hline Sintomáticos & 17 & $65.385 \%$ \\
\hline Oligossintomáticos & 6 & $23.077 \%$ \\
\cline { 2 - 4 } Total & Assintomáticos & 3 & $11.538 \%$ \\
\hline
\end{tabular}

\subsection{Acompanhamento clínico da população de risco:}

Após o acompanhamento clínico das 184 crianças com 4 a 10 anos de idade durante os anos de 2009 e 2010, como descrito no item 4.1.3 de materiais e métodos, 
não encontramos nenhuma criança com os sintomas clínicos característico de LV humana na população analisada.

\subsection{Teste de cultura in vitro das biópsias:}

Todas as biópsias coletadas foram divididas em três partes, sendo que uma parte foi utilizada para a realização do teste de cultura in vitro na tentativa de isolar e verificar a presença de formas promastigotas de Leishmania. Após um período de 2 à 5 semanas percebemos o crescimento das promastigotas em várias amostras analisadas e, dessa forma, conseguimos isolar os parasitos em 18 dos 26 cães soropositivos para LVC, como indica a tabela 2. Vale ressaltar que as amostras de cultura in vitro só foram classificadas como negativas quando o meio de cultura não apresentava nenhum tipo de propagação celular após 40 dias de observação. Desta forma verificamos que apenas quarto dos vinte e seis cães analisados apresentaram resultados negativos para todas as culturas dos 4 tecidos realizados.

Os fragmentos provenientes do tecido de baço e linfonodo foram os que apresentaram o maior índice de crescimento de parasitos com $69,23 \%$ de positividade nas amostras testadas. As amostras provenientes do baço também apresentaram o menor índice de contaminação com apenas 3,84\% de infecção das amostras testadas, evidenciando o melhor rendimento para o teste de cultura in vitro entre os tecidos analisados. Os maiores índices de contaminação foram verificados nas amostras provenientes da pele com lesão (seis amostras contaminadas, ou 23,07\%). Outra observação pertinente foi referente ao número total de amostras não contaminadas, pois do total de 104 amostras testadas apenas 14 culturas contaminaram refletindo um 
índice muito alto $(86,53 \%)$ de amostras não contaminadas. Essa eficiência pode ser decorrente da utilização do nosso protocolo de coleta empregado com rigor no local de coleta das amostras caninas.

Finalmente, ao analisarmos estatisticamente os resultados dos testes de cultura in vitro entre os diferentes tecidos avaliados pelo método do Chi-quadrado $\left(\chi^{2}\right)$, verificamos uma possível diferença significativa entre os resultados apresentados (valor de $p=0,056)$.

Tabela 2 - Resultado da cultura in vitro das amostras de diferentes tecidos dos 26 cães eutanasiados.

\begin{tabular}{c|c|c|c}
\hline \multirow{2}{*}{$\begin{array}{c}\text { Tecidos dos 26 cães } \\
\text { sorologicamente positivos }\end{array}$} & \multicolumn{3}{|c}{ Cultura in vitro em meio 199 } \\
\cline { 2 - 4 } & Positiva & Negative & Contaminada \\
\hline Baço & $18(69,23 \%)$ & $7(26,92 \%)$ & $1(3,84 \%)$ \\
\hline Lifonodo & $18(69,23 \%)$ & $4(15,38 \%)$ & $4(15,38 \%)$ \\
\hline Pele sem lesão & $15(57,69 \%)$ & $8(30,76 \%)$ & $3(11,53 \%)$ \\
\hline Pele com lesão & $15(57,69 \%)$ & $5(19,23 \%)$ & $6(23,07 \%)$ \\
\hline
\end{tabular}

\subsection{Teste parasitológico direto para a pesquisa de formas amastigotas nas amostras de tecido:}

Para melhor avaliar a infecção da LVC nos tecidos dos 26 cães eutanasiados, as amostras coletadas de cada tecido foram examinadas por pesquisa direta dos 
parasitos nas lâminas coradas (Teste direto). Foram feitos dois tipos de procedimentos para a leitura das lâminas 1) "imprinting" corados com Giemsa e 2) cortes histológicos corados com HE.

Quando comparávamos o mesmo tipo de tecido canino com as diferentes metodologias de coloração celular, verificamos que o teste direto corado com Giemsa apresentava formas celulares mais fidedignas à morfologia clássica da forma amastigota, portanto mais fáceis de serem identificadas do que nos cortes histológicos corados com HE. Essa observação pode ser explicada pela metodologia de coloração, pois para se realizar cortes histológicos corados com HE os tecidos passam por etapas de desidratação, clareamento, impregnação com parafina, inclusão e coloração o que pode alterar a morfologia da célula, apresentando células menores e até um pouco mais arredondas e/ou achatadas, como podemos ver na figura 1.

(A)

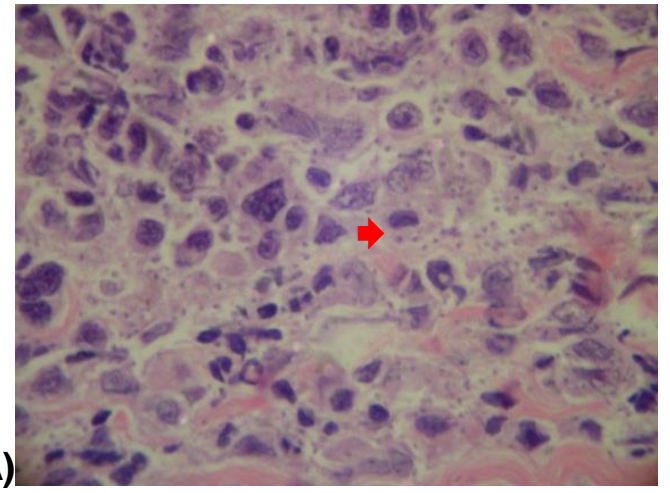

(B)

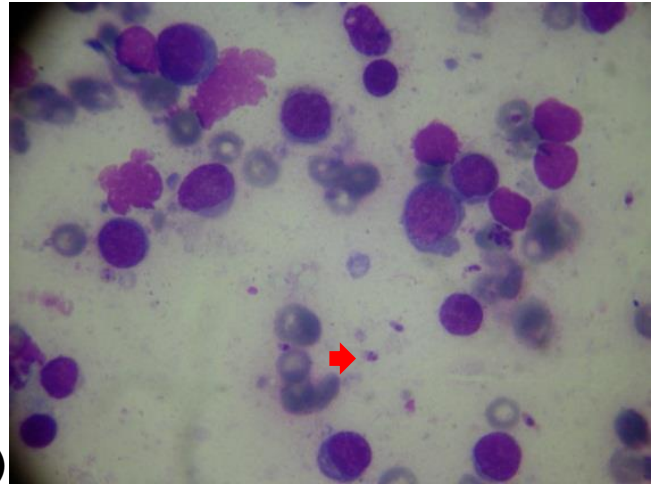

Figura 1: Lâminas analisadas em microscópio óptico NIKON Eclipse E200 com objetiva de 100X em imersão.

(A) Lâmina de pele com lesão do cão EB001 corada com HE;

(B) Lâmina de "imprinting" de pele com lesão do cão EB001 corada com Giemsa.

Mesmo assim, apresentamos os resultados das duas colorações a título de comparação (Tabelas 3 e 4). Verificamos que o teste direto corado com Giemsa apresentou uma maior quantidade de lâminas positivas com 73,08\% das lâminas 
provenientes das amostras de baço e pele com lesão, seguido por $69,23 \%$ das amostras de pele sem lesão e $65,38 \%$ das amostras de linfonodo. Já o teste direto corado com HE apresentou maior desempenho nas amostras provenientes do linfonodo com $65,38 \%$, seguido pelas amostras provenientes do baço $(61,14 \%)$, pele sem lesão $(53,85 \%)$ e pele com lesão $(34,62 \%)$, como podemos verificar nas tabelas 3 e 4.

Apesar do procedimento de coloração com Giemsa apresentar formas celulares mais fidedignas a forma amastigota, nós encontramos 19 das 104 lâminas com formas sugestivas, mas não claramente características de formas amastigotas. Verificamos ainda que 12 das 104 lâminas eram negativas, ou seja, sem nenhuma forma característica ou sugestiva de amastigota.

Já no teste direto com HE, a quantidade de lâminas sugestivas foi um pouco maior quando comparada com a coloração com Giemsa, apresentando 24 lâminas sugestivas, e 24 lâminas negativas.

Apesar do desempenho das duas metodologias de coloração das lâminas de pesquisa direta (Giemsa e HE) não terem apresentado resultados com diferença estatisticamente significativa quando analisadas pelo teste do Chi-quadrado $\left(\chi^{2} \mathrm{p}=\right.$ 0,981), optamos por utilizar na comparação final com as outras metodologias diagnósticas os resultados obtidos apenas com a coloração por Giemsa, pois observamos que este tipo de coloração (Giemsa) apresentou formas mais fidedignas à morfologia clássica da forma amastigota, dando maior credibilidade aos resultados encontrados (tabela 3). 
Martins TFC

Tabela 3 - Resultado da pesquisa de formas amastigotas em lâminas coradas com Giemsa.

\begin{tabular}{c|c|c|c|c|c|c|c|c|c}
\hline \multirow{2}{*}{ Amostras } & \multicolumn{2}{|c|}{ Baço } & \multicolumn{2}{c|}{ Linfonodo } & \multicolumn{2}{c|}{$\begin{array}{c}\text { Pele sem } \\
\text { Lesão }\end{array}$} & \multicolumn{2}{c}{$\begin{array}{c}\text { Pele com } \\
\text { Lesão }\end{array}$} & Total \\
\cline { 2 - 9 } & № & $\%$ & № & $\%$ & № & $\%$ & № & $\%$ & \\
\hline Positivos & 19 & 73,08 & 17 & 65,38 & 18 & 69,23 & 19 & 73,08 & $\begin{array}{c}73 \\
(70,19 \%)\end{array}$ \\
\hline Sugestivos & 4 & 15,38 & 6 & 23,08 & 5 & 19,23 & 4 & 15,38 & $\begin{array}{c}19 \\
(18,26 \%)\end{array}$ \\
\hline Negativos & 3 & 11,54 & 3 & 11,54 & 3 & 11,54 & 3 & 11,54 & $\begin{array}{c}12 \\
(11,53 \%)\end{array}$ \\
\hline Total & 26 & & 26 & & 26 & & 26 & & 104 \\
\hline
\end{tabular}

Tabela 4 - Resultado da pesquisa de formas amastigotas em lâminas coradas com HE.

\begin{tabular}{c|c|c|c|c|c|c|c|c|c}
\hline \multirow{2}{*}{ Amostras } & \multicolumn{2}{|c|}{ Baço } & \multicolumn{2}{c|}{ Linfonodo } & \multicolumn{2}{c|}{$\begin{array}{c}\text { Pele sem } \\
\text { Lesão }\end{array}$} & \multicolumn{2}{c|}{$\begin{array}{c}\text { Pele com } \\
\text { Lesão }\end{array}$} & Total \\
\cline { 2 - 9 } & № & $\%$ & № & $\%$ & № & $\%$ & № & $\%$ & \\
\hline Positivos & 16 & 61,54 & 17 & 65,38 & 14 & 53,85 & 9 & 34,62 & $\begin{array}{c}\mathbf{5 6} \\
(53,84 \%)\end{array}$ \\
\hline Sugestivos & 7 & 26,92 & 6 & 23,08 & 4 & 15,38 & 7 & 26,92 & $\begin{array}{c}\mathbf{2 4} \\
(23,07 \%)\end{array}$ \\
\hline Negativos & 3 & 11,54 & 3 & 11,54 & 8 & 30,76 & 10 & 38,46 & $\begin{array}{c}\mathbf{2 4} \\
(23,07 \%) \\
\mathbf{1 0 4}\end{array}$ \\
\hline Total & 26 & & 26 & & 26 & & 26 & & \multicolumn{1}{|c|}{} \\
\hline
\end{tabular}




\subsection{Resultados das reações de PCR:}

\subsubsection{Resultados da kDNA- PCR com as diferentes amostras de tecido:}

Após a padronização da reação de PCR com os iniciadores dirigidos ao kDNA (como descrito no item 4.5 de materiais e métodos), realizamos as reações de PCR em todas as amostras coletadas dos diferentes tecidos dos 26 cães eutanasiados. Para compararmos a eficiência da PCR utilizamos ainda amostras de pele sem lesão e de sangue total de um grupo de 28 cães com sorologia negativa para LVC coletados na mesma região (item 4.1 de materiais e métodos).

O controle positivo das reações foi realizado com amostras de DNA provenientes das espécies controle (item 4.2. de materiais e métodos). Todas as reações de PCR foram realizadas em duplicata e quando as reações apresentavam resultado negativo, eram submetidas à reação de PCR com iniciadores voltados ao gene que codifica a proteína beta-actina. Caso esta reação fosse negativa, nós repetiríamos a extração de DNA a partir do tecido.

Os resultados da reação de PCR estão representados na tabela 5, onde verificamos que as amostras de pele com lesão apresentaram maior positividade 25/26 (ou $96,15 \%$ ), seguida pelas amostras provenientes do baço $23 / 26$ (ou $88,46 \%$ de positividade); e pelas amostras de linfonodo e pele sem lesão, ambas com $80,77 \%$ de positividade. As reações de PCR com as amostras de sangue total apresentaram uma sensibilidade mais baixa de apenas $73,08 \%$, quando comparada com os outros tecidos analisados. 
Curiosamente, verificamos que nas amostras de sangue do grupo controle dos cães com sorologia negativa para LVC, $3 / 28$ (três dos vinte e oito cães ou 10,71\%) apresentaram amplificação do kDNA nas reações de PCR, e nas amostras de pele sem lesão do mesmo grupo de cães, verificamos que 1 cão apresentou amplificação na reação de PCR, sendo que este mesmo cão também foi positivo na amostra de sangue. Obviamente não poderíamos comparar os mesmos tecidos avaliados no grupo de cães com sorologia positiva, pois não seria ético realizar a biópsia de cães saudáveis.

Ao analisarmos estatisticamente os resultados obtidos no teste kDNA-PCR pelo Chi-quadrado $\left(\chi^{2}\right)$, verificamos também que o uso dos diferentes tecidos não apresentou diferença significativa para a sensibilidade do teste $\left(\chi^{2}\right.$ valor de $\left.p=0,341\right)$.

Também avaliamos de forma estatística a uniformidade dos resultados obtidos nos diferentes tecidos de pele sem lesão e sangue, entre o grupo de cães sorologicamente positivos e negativos pelo teste exato de Fisher. Verificamos que os resultados obtidos na kDNA-PCR por este grupo de amostras apresentaram-se uniformes, ou seja, sem diferença significativa entre o uso desses dois tecidos para a sensibilidade do teste, sendo que os resultados estão de acordo com o intervalo de confiança do teste exato de Fischer com valor de $p=0,611$ (tabela 5). 
Tabela 5 - Resultados da reação de PCR utilizando iniciadores kDNA nos diferentes tecidos de biopsia canina.

\begin{tabular}{|c|c|c|c|}
\hline & Tecidos & Positivo & Negativo \\
\hline \multirow{5}{*}{ 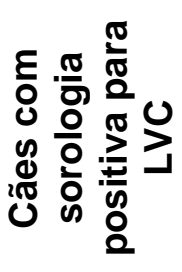 } & Baço & $23(88,46 \%)$ & $3(11,57 \%)$ \\
\hline & Linfonodo & $21(80,76 \%)$ & $5(19,24 \%)$ \\
\hline & Pele sem lesão & $21(80,76 \%)$ & $5(19,24 \%)$ \\
\hline & Pele com lesão* & $25(96,15 \%)$ & $1(3,85 \%)$ \\
\hline & Sangue total ${ }^{\star}$ & $19(73,07 \%)$ & 7 (26,93\%) \\
\hline \multirow{2}{*}{ 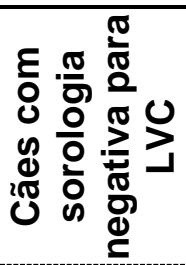 } & Sangue total* & $3(10,71 \%)$ & $25(89,28 \%)$ \\
\hline & Pele sem lesão* & $1(3,57 \%)$ & $27(96,43 \%)$ \\
\hline
\end{tabular}

* Análise estatística pelo teste exato de Fischer entre os resultados obtidos pelos 54 cães (26 sorologicamente positivos e 28 sorologicamente negativos) para verificar a uniformidade dos resultados da kDNA-PCR utilizando o grupo de cães negativos como controle da reação. Utilizando intervalo de confiança de $\alpha=0,05$; Com valor de $p=0,611$.

\subsubsection{Resultados da hsp70- PCR com as diferentes amostras de tecido:}

As amostras de DNA extraídas dos diferentes tecidos coletados dos cães soropositivos, também foram testadas com um iniciador de PCR considerado mais específico que o kDNA, o hsp70 (Graça et al. 2012) (como descrito no item 4.5). No entanto, a sensibilidade da reação foi inferior quando comparada com os resultados da kDNA-PCR, apresentando como resultado positivo apenas 20 dos 26 (76,92\%) cães analisados, verificado quando utilizamos as amostras provenientes do aspirado de linfonodo e pele sem lesão foram testadas (tabela 6). 
Um resultado interessante é que diferentemente do teste kDNA-PCR, nenhuma das amostras do grupo controle de cães com sorologia negativa foram positivas para as reações de hsp70-PCR. Vale ressaltar que todas as amostras testadas são amostras clínicas, e os resultados foram feitos em duplicata.

Também não verificamos nenhuma diferença significativa quando analisamos estatisticamente pelo método do $\chi^{2}$ os resultados obtidos quando os diferentes tecidos foram analisados pelo teste $h s p 70-P C R\left(\chi^{2}\right.$ valor de $\left.p=0,908\right)$.

Os resultados obtidos pelos dois testes moleculares (kDNA-PCR e hsp70-PCR, tabelas 5 e 6) utilizando os tecidos de pele sem lesão e sangue dos cães com sorologia positiva e negativa, foram analisados entre si para avaliar o índice de concordância entre as duas metodologias. Dessa forma, verificamos que o índice Kappa (к) (com intervalo de confiança de 95\% de probabilidade) indicou uma boa concordância entre as duas técnicas, com $\kappa=0,689(0,491-0,887)$.

Tabela 6 - Resultados da reação de PCR utilizando iniciadores $h s p 70$ nos diferentes tecidos de biopsia canina.

\begin{tabular}{|c|c|c|c|}
\hline & Tecidos & Positivo & Negativo \\
\hline \multirow{5}{*}{ 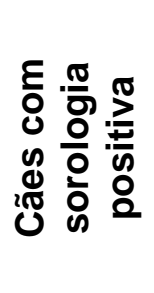 } & Baço & $19(73,07 \%)$ & $7(26,93 \%)$ \\
\hline & Linfonodo & $20(76,92 \%)$ & $6(23,08 \%)$ \\
\hline & Pele sem lesão & $20(76,92 \%)$ & $6(23,08 \%)$ \\
\hline & Pele com lesão & $18(69,23 \%)$ & $8(30,77 \%)$ \\
\hline & Sangue & 15 (57,69\%) & $11(42,31 \%)$ \\
\hline \multirow{2}{*}{ 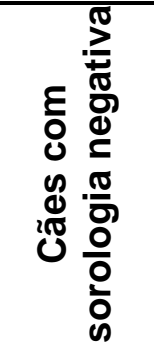 } & Pele sem lesão & 0 & 28 \\
\hline & Sangue & 0 & 28 \\
\hline
\end{tabular}




\subsection{Comparação entre os resultados da cultura in vitro, exame direto e PCR dos cães positivos:}

A tabela 7 representa a comparação entre os resultados do cultivo in vitro, pesquisa de formas amastigotas pelo exame direto com Giemsa e amplificação por PCR com dois iniciadores diferentes das amostras dos diferentes tecidos coletados dos 26 cães com sorologia positiva para LVC.

Notamos que as reações de amplificação por PCR apresentaram índices de positividade maiores do que os exames parasitológicos clássicos, como esperado. Verificamos também que as reações de PCR utilizando os iniciadores dirigidos para o kDNA apresentaram índices de positividade maiores variando de $96,15 \%$ a $73.08 \%$ (nas amostras de pele com lesão e sangue, respectivamente), enquanto que as reações utilizando os iniciadores dirigidos para o hsp70 apresentaram índices um pouco menores (variando de $76,92 \%$ a $57,69 \%$ nas amostras de linfonodo e sangue, respectivamente); por outro lado os índices de positividade verificados pelos exame parasitológicos clássicos atingiram o máximo de 73,08\% (exame direto, com amostras de baço e pele com lesão).

Se por outro lado compararmos, apenas os índices de positividade dos testes realizados com as amostras de pele sem lesão notamos que o índice verificado para a reação de kDNA-PCR $(96,15 \%)$ é 1,66 vezes maior do que o obtido pelo cultivo in vitro $(57,69 \%)$, indicando, por esse critério, que a reação de kDNA-PCR seria a mais sensível quando comparadas com os outros testes analisados. Essa observação é também válida para todos os outros tecidos analisados por essa comparação. 
Tabela 7- Comparação entre as técnicas de cultura in vitro do parasito, Pesquisa direta em lâminas coradas com Giemsa e a reação de PCR (kDNA e hsp70) nos diferentes tecidos dos cães soropositivos.

\begin{tabular}{c|c|c|c|c|c}
\hline $\begin{array}{c}\text { Tecidos dos } \\
\text { cães positivos } \\
\text { para LVC }\end{array}$ & $\begin{array}{c}\text { Cultivo in } \\
\text { vitro }\end{array}$ & $\begin{array}{c}\text { Pesq. Direta } \\
\text { em lâminas } \\
\text { coradas com } \\
\text { Giemsa }\end{array}$ & kDNA-PCR & hsp70-PCR & $\mathbf{P}^{(\mathrm{a})}$ \\
\hline & Numero e (\%) & Numero e (\%) & Numero e (\%) & Numero e (\%) & \\
\hline Pele com lesão & $15 / 26(57,69 \%)$ & $19 / 26(73,08 \%)$ & $25 / 26(96,15 \%)$ & $18 / 26(69,23 \%)$ & 0,005 \\
\hline Baço & $18 / 26(69,23 \%)$ & $19 / 26(73,08 \%)$ & $23 / 26(88,46 \%)$ & $19 / 26(73,07 \%)$ & 0,016 \\
\hline Pele sem lesão & $15 / 26(57,69 \%)$ & $18 / 26(69,23 \%)$ & $21 / 26(80,77 \%)$ & $20 / 26(76,92 \%)$ & 0,010 \\
\hline Linfonodo & $18 / 26(69,23 \%)$ & $17 / 26(65,38 \%)$ & $21 / 26(80,77 \%)$ & $20 / 26(76,92 \%)$ & 0,010 \\
\hline Sangue & & $14 / 26(46,15 \%)$ & $19 / 26(73,08 \%)$ & $15 / 26(57,69 \%)$ & - \\
\hline
\end{tabular}

(a) - Valores de $p$ foram calculados pelo teste de $X^{2}$, baseado na análise comparativa entre a utilização de cada tecido em relação a sensibilidade dos testes. Com $p \leq 0,05$.

Os resultados dessas comparações foram analisados estatisticamente pelo método do Chi-Quadrado, $\chi^{2}$, que permite avaliar mais de duas variáveis ao mesmo tempo e também indica se existe uma relação entre os resultados dos tecidos avaliados com a metodologia utilizada, como descrito no item 4.9.1 de materiais e métodos.

Dessa forma, comparamos os resultados de cada um dos diferentes tecidos analisado com os 4 testes diagnósticos. Por exemplo, verificamos na tabela 7 que a comparação dos resultados dos testes diagnósticos com as amostras de pele com lesão foi significativamente diferente entre os testes utilizados, o que confirma a hipótese levantada anteriormente de que a reação de kDNA-PCR seria a mais sensível quando comparadas com os outros testes analisados. Da mesma forma, resultados 
estatisticamente significativos foram encontrados quando analisarmos todos os outros

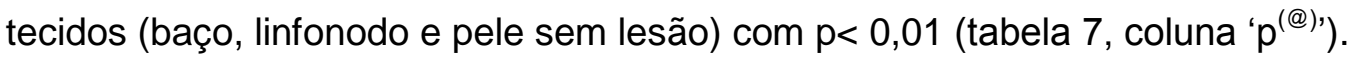

\subsubsection{Comparação entre os resultados das PCRs com o teste parasitológico direto em cada um dos cães positivos:}

Para avaliarmos com mais detalhes a eficiência da reação de kDNA-PCR comparamos individualmente os resultados da amplificação por PCR de cada tecido em cada um dos cães com os respectivos dados clínicos e dos testes parasitológicos clássicos. Para tanto, consideramos os resultados do cultivo in vitro, exame direto com Giemsa e exame direto HE, em um único grupo chamado "teste parasitológico", onde consideramos como positivo o cão que apresentasse resultado positivo em pelo menos um dos tecidos avaliados em pelo menos um dos três testes parasitológicos realizados (tabelas 8 e 9). Por outro lado, definimos como resultados negativos, apenas os cães que apresentavam resultados negativos em todos os tecidos avaliados. Quando o resultado apresentava formas sugestivas e indefinidas ou a cultura contaminava determinamos o resultado como inconclusivo.

Interessantemente, ao avaliarmos os resultados dos testes parasitológicos clássicos dessa maneira, percebemos que três cães foram considerados negativos por esses critérios (os cães EB012, EB016 e EB023). Esses cães apresentaram resultados negativos em todas as amostras de tecidos avaliadas pelos três testes parasitológicos clássicos realizados, ou seja, foram ao todo consideradas doze (12) reações negativas para cada cão (3 testes realizados com amostras de 4 tecidos diferentes). 
Observamos ainda que o cão EB012 além de apresentar resultado negativo em todos os 12 testes parasitológicos mais o resultado de duas reações de PCR (kDNA e hsp70) nos 4 tecidos diferentes (perfazendo um total de 20 testes diferentes com resultados negativos), era também assintomático (em destaque nas tabelas 8 e 9).

Tabela 8 - Resultados da kDNA-PCR comparados aos resultados do teste parasitológico direto* de cada um dos 26 cães soropositivos.

\begin{tabular}{|c|c|c|c|c|c|c|}
\hline Cão & Baço & Linfonodo & Pele sem lesão & Lesão $^{(a)}$ & $\begin{array}{c}\text { Teste } \\
\text { Parasitológico } \\
\end{array}$ & $\begin{array}{c}\text { Avaliação clínica } \\
\text { dos cães }\end{array}$ \\
\hline EB001 & $P$ & $P$ & $P$ & $P$ & $P$ & Sint. \\
\hline EBO02 & $P$ & $P$ & $\mathrm{P}$ & $P$ & $P$ & Sint. \\
\hline EBO03 & $\mathrm{P}$ & $\mathrm{P}$ & $\mathrm{P}$ & $\mathrm{P}$ & $\mathrm{P}$ & Olig. \\
\hline EBO04 & $P$ & $\mathrm{P}$ & $\mathrm{P}$ & $\mathrm{P}$ & INC & Sint. \\
\hline EB005 & $P$ & $P$ & $P$ & $P$ & $P$ & Sint. \\
\hline EB006 & $\mathrm{P}$ & $\mathrm{P}$ & $\mathrm{P}$ & $\mathrm{P}$ & $\mathrm{P}$ & Sint. \\
\hline EB007 & $P$ & $P$ & $\mathrm{P}$ & $\mathrm{P}$ & $P$ & Sint. \\
\hline EB008 & $P$ & $\mathrm{P}$ & $\mathrm{P}$ & $\mathrm{P}$ & $P$ & Sint. \\
\hline EB009 & $P$ & $P$ & $\mathrm{P}$ & $\mathrm{P}$ & $\mathrm{P}$ & Sint. \\
\hline EB010 & $P$ & $P$ & $P$ & $\mathrm{P}$ & $P$ & Sint. \\
\hline EB011 & $P$ & $P$ & $\mathrm{P}$ & $P$ & $P$ & Olig. \\
\hline EB012 & $\mathrm{N}$ & $\mathrm{N}$ & N & N & $\mathrm{N}$ & Assi. \\
\hline EB013 & $P$ & $P$ & $\mathrm{P}$ & $P$ & $\mathrm{P}$ & Sint. \\
\hline EB014 & $\mathrm{P}$ & $\mathrm{P}$ & $\mathrm{P}$ & $\mathrm{P}$ & $\mathrm{P}$ & Sint. \\
\hline EB015 & $\mathrm{P}$ & $\mathrm{N}$ & $\mathrm{N}$ & $P$ & INC & Olig. \\
\hline EB016 & $\mathrm{N}$ & $N$ & $\mathrm{~N}$ & $\mathrm{P}$ & $N$ & Assi. \\
\hline EB017 & $\mathrm{P}$ & $\mathrm{P}$ & $\mathrm{P}$ & $\mathrm{P}$ & $P$ & Sint. \\
\hline EB018 & $P$ & $P$ & $\mathrm{P}$ & $P$ & $P$ & Olig. \\
\hline EB019 & $P$ & $P$ & $\mathrm{P}$ & $P$ & $P$ & Sint. \\
\hline EB020 & $P$ & $P$ & $\mathrm{P}$ & $P$ & $\mathrm{P}$ & Assi. \\
\hline EB021 & $P$ & $P$ & $\mathrm{P}$ & $\mathrm{P}$ & $P$ & Sint. \\
\hline EB022 & $P$ & $P$ & $P$ & $P$ & $P$ & Olig. \\
\hline EB023 & $P$ & $\mathrm{~N}$ & $\mathrm{~N}$ & $P$ & $N$ & Sint. \\
\hline EB024 & $\mathrm{N}$ & $\mathrm{N}$ & $\mathrm{N}$ & $P$ & INC & Olig. \\
\hline EBO25 & $\mathrm{P}$ & $\mathrm{P}$ & $\mathrm{P}$ & $\mathrm{P}$ & $\mathrm{P}$ & Sint. \\
\hline EBO26 & $P$ & $P$ & $\mathrm{P}$ & $P$ & $P$ & Sint. \\
\hline
\end{tabular}

(P) resultados positivos; (N) resultados negativos; (INC) resultados inconclusivos; (Sint.) sintomático; (Olig.) oligossintomático; (Assi.) assintomático.

(a) - Valor de $\mathbf{p}=0,0047$, Valores de $\mathbf{p}$ foram calculados pelo teste de $X^{2}$ com $p \leq 0,005$ 
Tabela 9 - Resultados da hsp70-PCR comparados aos resultados do teste parasitológico direto* de cada um dos 26 cães soropositivos.

\begin{tabular}{|c|c|c|c|c|c|c|}
\hline Amostras & Baço & Linfonodo & Pele & Lesão & $\begin{array}{l}\text { Parasitológico } \\
\text { Direto }\end{array}$ & $\begin{array}{l}\text { Avaliação clínica dos } \\
\text { cães }\end{array}$ \\
\hline EB001 & $P$ & $P$ & $P$ & $P$ & $P$ & Sint. \\
\hline EB002 & $\mathrm{P}$ & $P$ & $\mathrm{P}$ & $P$ & $P$ & Sint. \\
\hline EB003 & $\mathrm{P}$ & $\mathrm{P}$ & $\mathrm{P}$ & $P$ & $\mathrm{P}$ & Olig. \\
\hline EB004 & $\mathrm{P}$ & $\mathrm{P}$ & $\mathrm{P}$ & $P$ & INC & Sint. \\
\hline EB005 & $\mathrm{P}$ & $\mathrm{P}$ & $\mathrm{P}$ & $P$ & $P$ & Sint. \\
\hline EB006 & $\mathrm{N}$ & $\mathrm{N}$ & $\mathrm{N}$ & $\mathrm{N}$ & $\mathrm{P}$ & Sint. \\
\hline EB007 & $\mathrm{P}$ & $\mathrm{P}$ & $\mathrm{P}$ & $\mathrm{N}$ & $\mathrm{P}$ & Sint. \\
\hline EB008 & $\mathrm{P}$ & $\mathrm{P}$ & $\mathrm{P}$ & $\mathrm{P}$ & $\mathrm{P}$ & Sint. \\
\hline EB009 & $P$ & $P$ & $P$ & $P$ & $P$ & Sint. \\
\hline EB010 & $P$ & $P$ & $P$ & $\mathrm{~N}$ & $P$ & Sint. \\
\hline EB011 & $\mathrm{P}$ & $\mathrm{N}$ & $\mathrm{N}$ & $\mathrm{P}$ & $\mathrm{P}$ & Olig. \\
\hline EB012 & $\mathrm{N}$ & $\mathrm{N}$ & $\mathrm{N}$ & $\mathrm{N}$ & $\mathrm{N}$ & Assi. \\
\hline EB013 & $P$ & $P$ & $\mathrm{~N}$ & $P$ & $P$ & Sint. \\
\hline EB014 & $P$ & $P$ & $P$ & $P$ & $P$ & Sint. \\
\hline EB015 & $\mathrm{N}$ & $P$ & $\mathrm{P}$ & $P$ & INC & Olig. \\
\hline EB016 & $\mathrm{N}$ & $\mathrm{N}$ & $\mathrm{N}$ & $\mathrm{N}$ & $\mathrm{N}$ & Assi. \\
\hline EB017 & $P$ & $P$ & $P$ & $P$ & $P$ & Sint. \\
\hline EB018 & $\mathrm{N}$ & $P$ & $P$ & $\mathrm{~N}$ & $\mathrm{P}$ & Olig. \\
\hline EB019 & $\mathrm{N}$ & $P$ & $\mathrm{~N}$ & $P$ & $\mathrm{P}$ & Sint. \\
\hline EB020 & $P$ & $P$ & $P$ & $\mathrm{~N}$ & $P$ & Assi. \\
\hline EB021 & $\mathrm{P}$ & $\mathrm{P}$ & $P$ & $\mathrm{P}$ & $P$ & Sint. \\
\hline EB022 & $\mathrm{P}$ & $\mathrm{P}$ & $\mathrm{P}$ & $\mathrm{P}$ & $P$ & Olig. \\
\hline EB023 & $\mathrm{N}$ & $\mathrm{N}$ & $\mathrm{P}$ & $\mathrm{P}$ & $\mathrm{N}$ & Sint. \\
\hline EB024 & $P$ & $\mathrm{~N}$ & $P$ & $\mathrm{~N}$ & INC & Olig. \\
\hline EB025 & $P$ & $P$ & $P$ & $P$ & $P$ & Sint. \\
\hline EB026 & P & $P$ & P & P & $P$ & Sint. \\
\hline
\end{tabular}

(P) resultados positivos; (N) resultados negativos; (INC) resultados inconclusivos; (Sint.) sintomático; (Olig.) oligossintomático; (Assi.) assintomático.

A análise estatística da comparação dos resultados dos testes realizados em cada cão foi feita utilizando o mesmo critério para dos "testes parasitológicos", ou seja, utilizando o teste do Chi-Quadrado $\chi^{2}$ (item 4.9.1 de Materiais e Métodos), verificamos 
que somente os resultados da reação de kDNA-PCR com as amostras de pele com lesão apresentaram diferença estatística significante para a sensibilidade da reação com valor de $\mathrm{p}=0,0047$ (tabela 8 ) ao passo que a reação de hsp70-PCR não apresentou diferença estatística em nenhum dos tecidos avaliados.

Ao avaliarmos estatisticamente a concordância (pelo teste de McNemar) entre os resultados apresentados pelos testes kDNA-PCR e hsp70-PCR com cada um dos tecidos, utilizando como padrão os testes parasitológicos, percebemos que da mesma forma que o teste $\chi^{2}$ a amostra de pele com lesão apresentou resultado significantemente discordante no teste kDNA-PCR em relação aos testes parasitológicos, indicando valor de $p=0,041$ (tabela 10 coluna $p^{(a)}$ ). Ou seja, os resultados obtidos pelos outros tecidos avaliados na kDNA-PCR (baço, linfonodo e pele com e sem lesão), assim como, todos os resultados obtidos na reação de hsp70PCR, não apresentaram diferença estatisticamente significante entre os resultados do teste parasitológico. Por outro lado, os resultados das amostras de pele sem lesão e linfonodo obtidos pelo teste kDNA-PCR apresentaram valor de $p=1,00$, o que significa que existiu alta concordância estatística entre os resultados obtidos neste tipo de tecido com os resultados obtidos pelos testes parasitológicos, indicando que a sensibilidade destas amostras nas duas metodologias (kDNA-PCR e parasitológico direto) foram iguais. 
Tabela 10 - Comparação entre os diferentes tecidos analisados nos testes moleculares (kDNA-PCR e hsp70-PCR) utilizando os testes parasitológicos como padrão ouro da reação

\begin{tabular}{|c|c|c|c|c|c|}
\hline $\begin{array}{l}\text { Tecidos dos } \\
\text { cães positivos } \\
\text { para LVC }\end{array}$ & $\begin{array}{c}\text { testes } \\
\text { parasitológicos }\end{array}$ & kDNA-PCR & $\mathbf{P}^{(\mathrm{a})}$ & Hsp70-PCR & $\mathbf{P}^{(\mathrm{b})}$ \\
\hline \multirow[b]{2}{*}{$\begin{array}{l}\text { Pele com } \\
\text { lesão }\end{array}$} & \multirow[b]{2}{*}{$20 / 26(76,92 \%)$} & Numero e (\%) & & Numero e (\%) & \multirow[b]{2}{*}{0,074} \\
\hline & & $25 / 26(96,15 \%)$ & 0,041 & $18 / 26(69,23 \%)$ & \\
\hline Baço & $21 / 26(80,76 \%)$ & $23 / 26(88,46 \%)$ & 0,863 & $19 / 26(73,07 \%)$ & 0,371 \\
\hline Pele sem lesão & 20/26 (76,92\%) & $21 / 26(80,77 \%)$ & 1 & $20 / 26(76,92 \%)$ & 0,134 \\
\hline Linfonodo & $20 / 26(76,92 \%)$ & $21 / 26(80,77 \%)$ & 1 & $20 / 26(76,92 \%)$ & 0,617 \\
\hline Sangue & 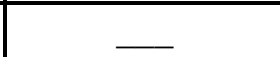 & $19 / 26(73,08 \%)$ & & $15 / 26(57,69 \%)$ & \\
\hline
\end{tabular}

(a) para o teste kDNA-PCR, utilizando os testes parasitológico como padrão ouro para a análise; (b) para o teste hsp70-PCR, utilizando os testes parasitológico como padrão ouro para a análise;

Finalmente verificamos ainda a especificidade da reação de kDNA-PCR e hsp70-PCR, com porcentagens de especificidade (tabela 11) de 100\% quando realizado com as amostras de baço no teste de kDNA-PCR, sendo que no teste de hsp70-PCR a amostra mais específica foi proveniente do aspirado de linfonodo com 86,96\%. Porém excluímos desta análise os resultados inconclusivos pelo teste parasitológico, e avaliamos essa especificidade em apenas 23 dos 26 cães eutanasiados. Essa avaliação foi realizada pela a análise estatística apresentada pelo teste de MacNemar. 
Tabela 11 - Especificidade dos testes de kDNA-PCR e hsp70-PCR em cada um dos tecido coletados dos cães soropositivos em comparação com o parasitológico direto

\begin{tabular}{c|c|c}
\hline \multirow{2}{*}{ Tecidos } & kDNA-PCR & hsp70-PCR \\
\cline { 2 - 3 } & Valor em \% & Valor em \% \\
\hline Baço & 100 & 82,61 \\
\hline Linfonodo & 91,30 & 86,96 \\
\hline Pele sem lesão & 91,30 & 82,61 \\
\hline Pele com lesão & 91,30 & 73,91 \\
\hline
\end{tabular}

\subsection{Identificação de espécies de Leishmania com a técnica de PCR-RFLP:}

Os produtos de DNA amplificados dos diferentes tecidos testados foram utilizados para a realização das reações de restrição enzimática, para identificarmos qual era a espécie de Leishmania envolvida na infecção canina da cidade de Embu das Artes.

Como controle positivo das reações utilizamos o produto da amplificação por kDNA-PCR e hsp70-PCR do DNA extraio das culturas das três principais espécies de Leishmania que estão envolvidas no desenvolvimento da leishmaniose no Brasil, (Leishmania (L.) infantum-chagasi, L. (L.) amazonensis e L. (Viannia) braziliensis, item 4.2). Assim, realizamos a técnica de PCR-RFLP com a enzima de restrição Haelll para os produtos de PCR amplificados com os iniciadores para kDNA, e com a enzima BsaJl seguida pela enzima EcoRI para os produtos de PCR amplificados com os iniciadores dirigidos para hsp70. 
Martins TFC

Os produtos de amplificação por kDNA-PCR digeridos com Haelll apresentaram um padrão de digestão diferente do esperado, ou seja: não digestão para Leishmania L. amazonensis e dois fragmentos de 80 e 40 pb para Leishmania (V.) braziliensis. Como pode ser observado nas figuras 2 e 3, verificamos um padrão de digestão apresentando o fragmento de 120 pb original, e um outro de aproximadamente $60 \mathrm{pb}$ sugerindo uma digestão parcial do fragmento original amplificado, que estamos sugerindo que seja indicativo da presença de Leishmania infantum-chagasi.

Por outro lado, verificamos um padrão de digestão característico de Leishmania infantum-chagasi quando o DNA das mesmas amostras foi amplificado com os iniciadores para o gene da hsp70 e digerido com Bsall (três fragmentos de 400, 110 e 83 pb (Figura 4), seguido da digestão desse mesmo produto com EcoRIl (dois fragmentos de 400 e 83 pb) (Figura 5), confirmando que a espécie envolvida era Leishmania infantum-chagas. Esses resultados estão de acordo com a hipótese inicial de infecção canina visceral que comumente é decorrente da infecção por Leishmania infantum-chagasi

Como havíamos isolado parasitos de $73,07 \%$ das amostras no cultivo in vitro, enviamos os parasitos para o Laboratório de Leishmaniose da Profa. Dra. Elisa Cupolillo da FIOCRUZ no Rio de Janeiro, onde foi possível confirmar por testes de isoenzimas que as espécies eram realmente Leishmania infantum-chagasi. 
Martins TFC

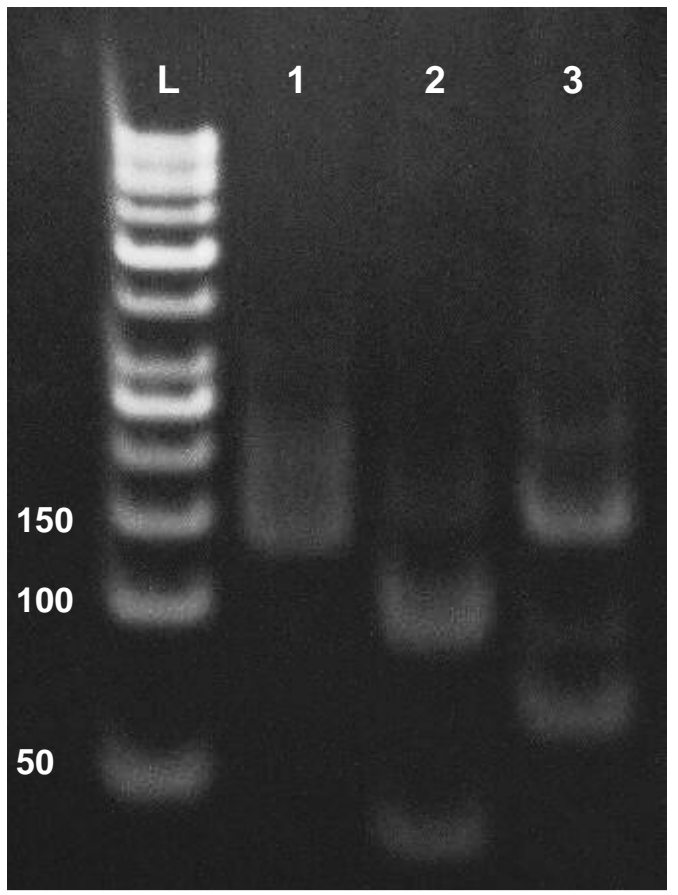

Figura 2 - Produtos da reação de kDNA-PCR seguidos por digestão enzimática com a enzima de restrição Hae III. L- Peso molecular 50 pb Low Range Fermentas; 1-L. amazonensis; 2- L. braziliensis; L- chagasi. 
Martins TFC

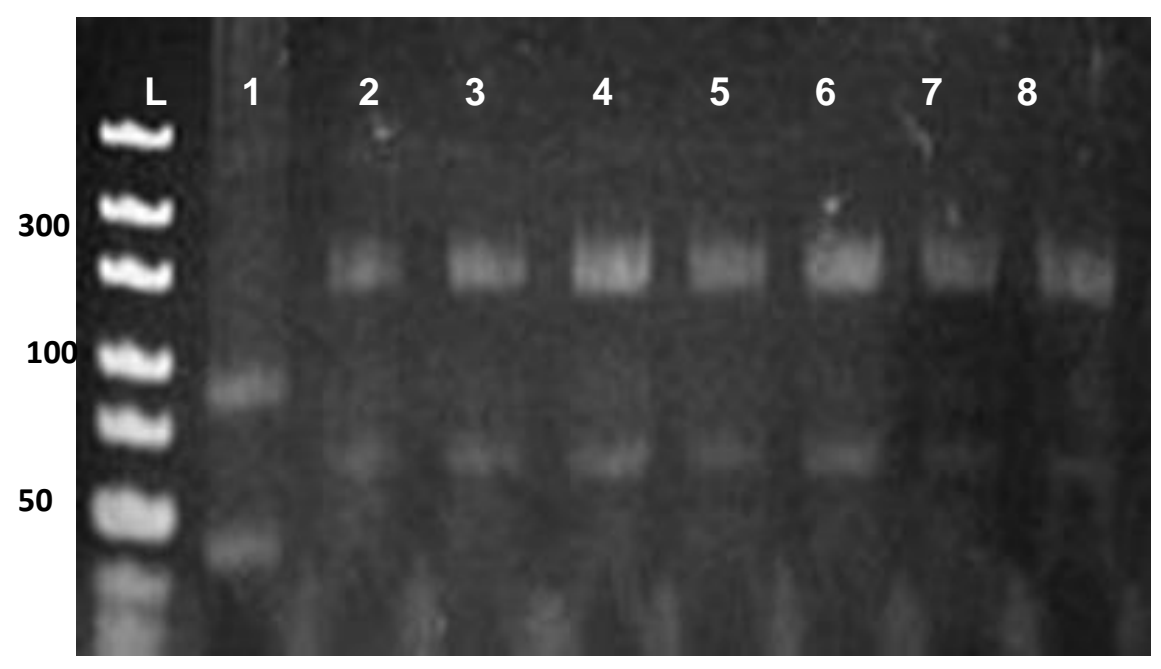

Figura 3 - Produtos da reação de kDNA-PCR seguidos por digestão enzimática com a enzima de restrição Hae III. LPeso molecular Ultra-Low Range Fermentas;1- L. baziliensis; 2-EB001 baço; 3-EB002 baço; 4-EB003 baço;5EB004 baço; 6-EB005 baço; 7-EB006 baço;8- EB007 baço

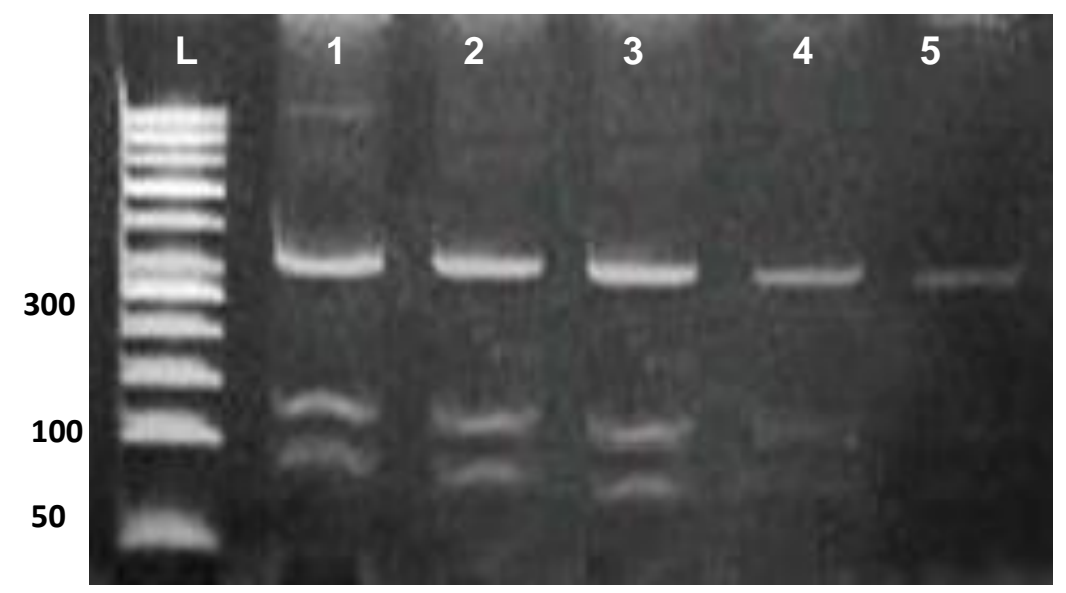

Figura 4 - Produtos da reação de hsp70-PCR seguidos por digestão enzimática com a enzima de restrição BsaJl. L- Peso molecular 50pb Low Range Fermentas; 1-L. chagasi. 2- EB001 baço; 3-EB003 baço; 4- EB005 baço; 5- EB007 baço. 
Martins TFC

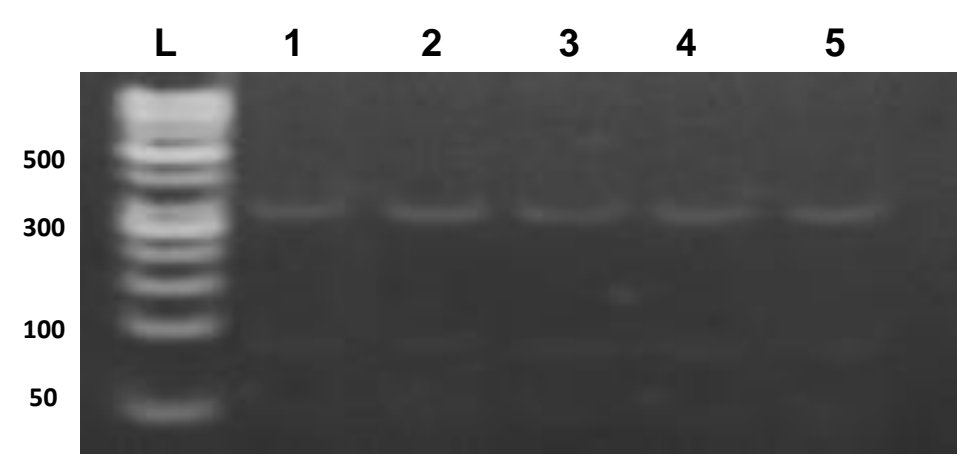

Figura 5 - Produtos da reação de hsp70-PCR seguidos por digestão enzimática com a enzima de restrição BsaJl e EcoRII. L- Peso molecular $50 \mathrm{pb}$ Low Range Fermentas; 1- Leishmania infantum-chagasi; 2-EB002 Linfonodo; 3-EB003 Linfonodo; 4- EB005 Linfonodo;5- EB007 linfonodo.

\subsection{Resultados da PCR em Tempo Real (qPCR):}

$\mathrm{Na}$ tentativa de aprimorar os resultados da identificação da espécie de Leishmania envolvida na infecção dos cães em cada um dos tecidos avaliados, utilizamos a técnica de qPCR com iniciadores dirigidos ao hsp70. Inicialmente geramos a curva de padronização utilizando oito (8) pontos de concentração diferentes (diluição seriada com razão de 1:10 - item 4.7.1) com os DNAs de culturas de Leishmania (L.) amazonensis, L. (V.) braziliensis e L. (L.) infantum-chagasi (figura 6). 
Martins TFC

Toda a análise desta técnica (qPCR) foi baseada nos parâmetros de tempo de ciclagem $\left(\mathrm{C}_{\mathrm{T}}\right)$ e temperaturas de dissociação ou Melting (TM) apresentadas por esta curva padrão, figura 6.

\section{Amplification Plot}

Plot Settings

Plot Type: $\triangle$ Rn vs Cycle - Graph Type: Log - Color: Well -

Save current settings as the default
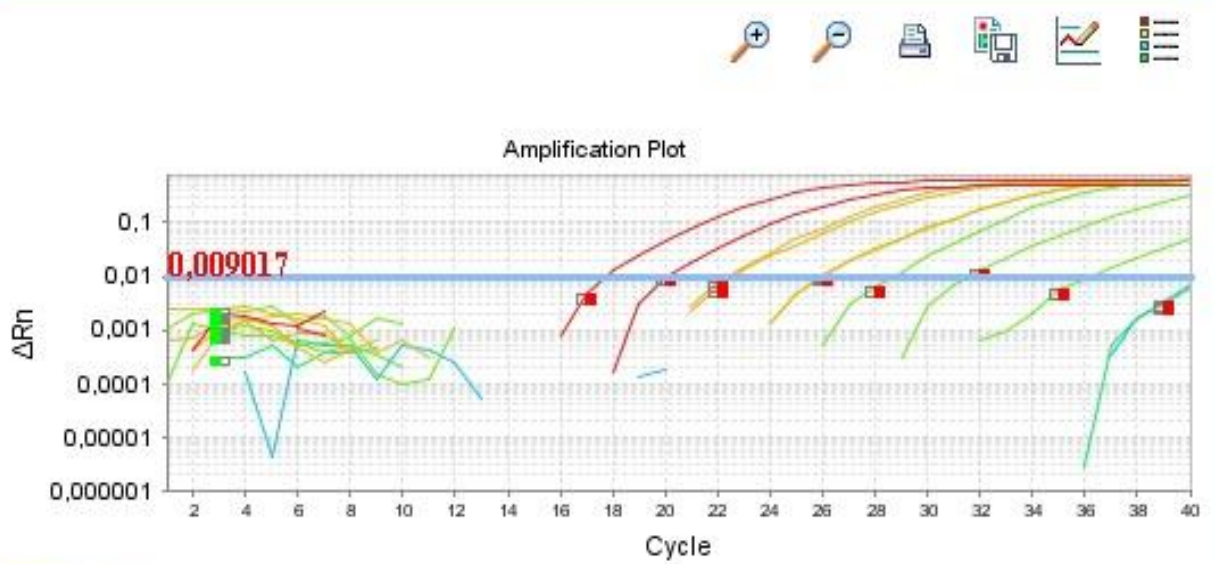

Options

Target: Hsp70 - Threshold: $\square$ Auto 0009017 - Auto Baseline

Show: $\nabla$ Threshold $-\nabla$ Baseline Start: Well 1 Target $\Delta$ Baseline End: Well $\mathbf{\square T a r g e t} \Delta$

Save current settings as the default

Analysis Summary: Total Wells in Plate: $96 \quad$ Wells Set Up: 80 Wells Omitted Manually: 1:

Figura 6 - Curva Padrão das amostras de DNA de Leishmania Resultado da amplificação do DNA de Leishmania infantum-chagasi pela técnica de Real-Time PCR na concentração de $10^{8}$ parasitas por $\mathrm{mL}$ a 10 parasitas por $\mathrm{mL}$. 
Martins TFC

Em seguida foi feita a dissociação da dupla fita de DNA (Melting Curve) de cada espécie de Leishmania indicada acima. Conforme podemos avaliar nas figuras 7, 8 e 9 não foi possível obter um padrão de diferenciação satisfatório para as espécies de Leishmania. Pode-se verificar que as TMs obtidas para as espécies de Leishmania amazonensis, Leishmania braziliensis e Leishmania infantum-chagasi foram semelhantes, apresentando temperaturas com menos de $1^{\circ} \mathrm{C}$ de diferença, variando entre $92,18^{\circ} \mathrm{C}$ e $91,63^{\circ} \mathrm{C}$, conforme representado respectivamente nas figuras 7,8 e 9 .

\section{Melt Curve}
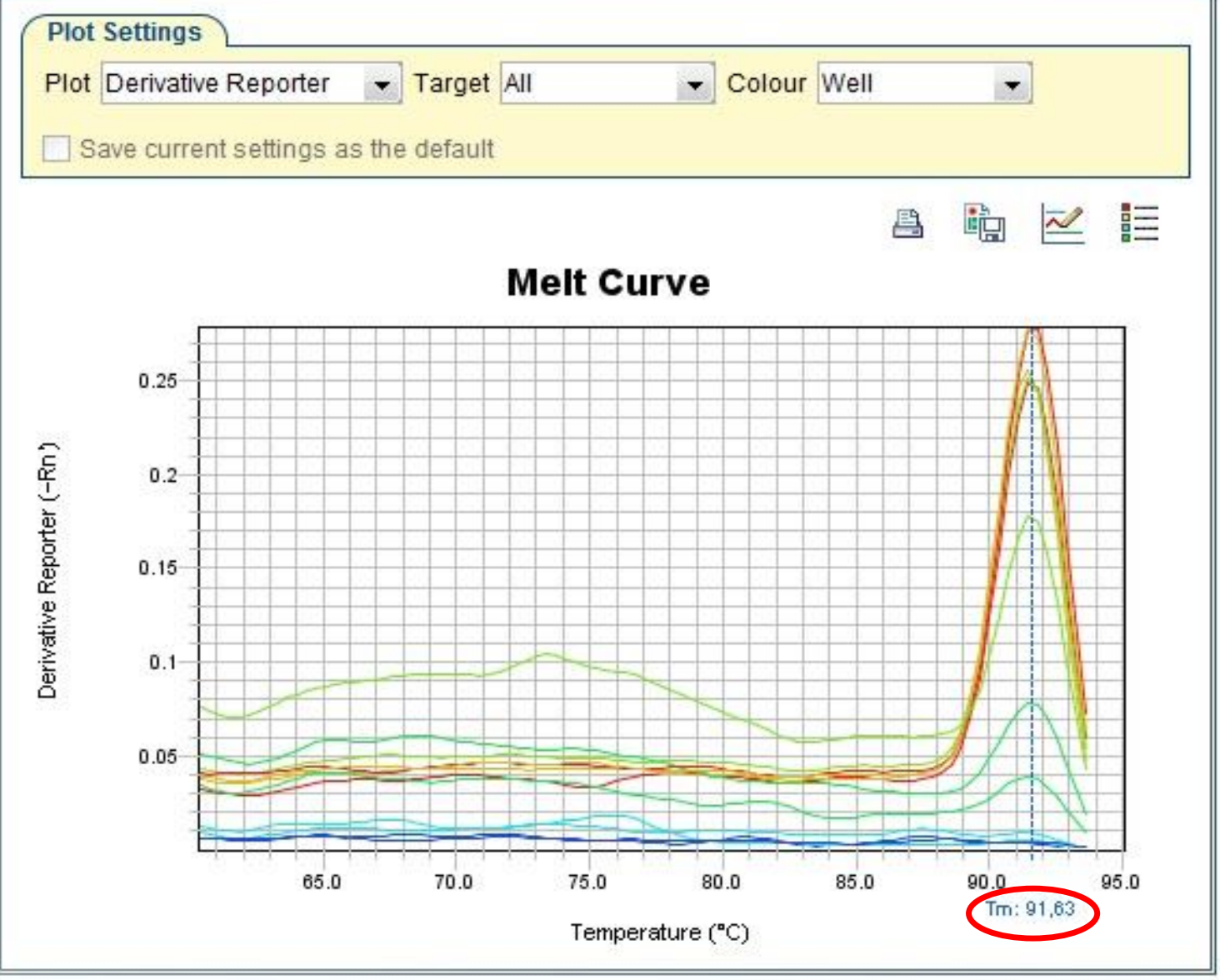

Figura 7- Resultado da Curva Melting da Real-Time PCR- Dissociação da Dupla fita de DNA após a amplificação do DNA de Leishmania amazonensis. 
Martins TFC

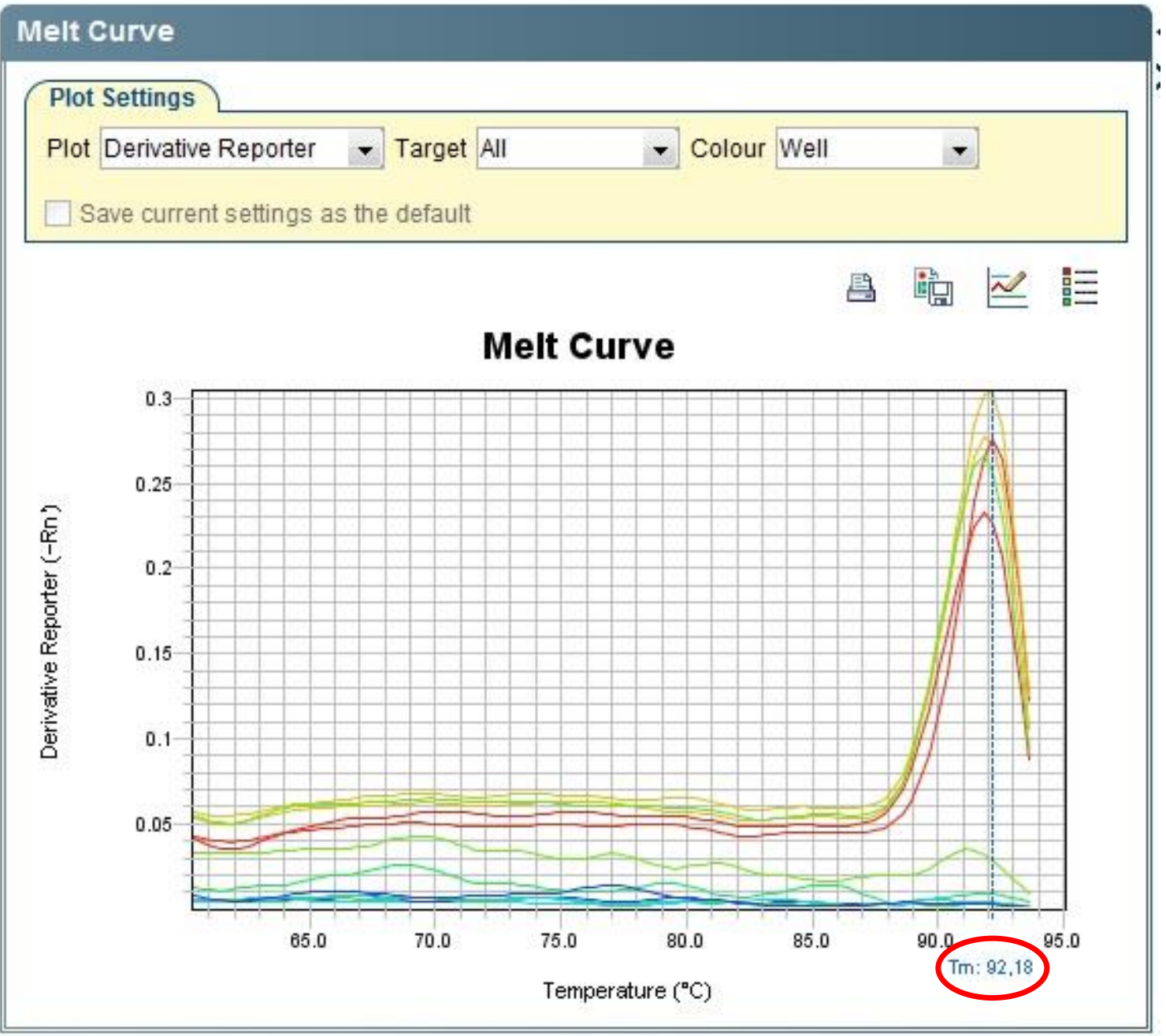

Figura 8 - Resultado da Curva Melting da Real-Time PCR- Dissociação da Dupla fita de DNA após a amplificação do DNA de Leishmania brasiliensis 
Martins TFC

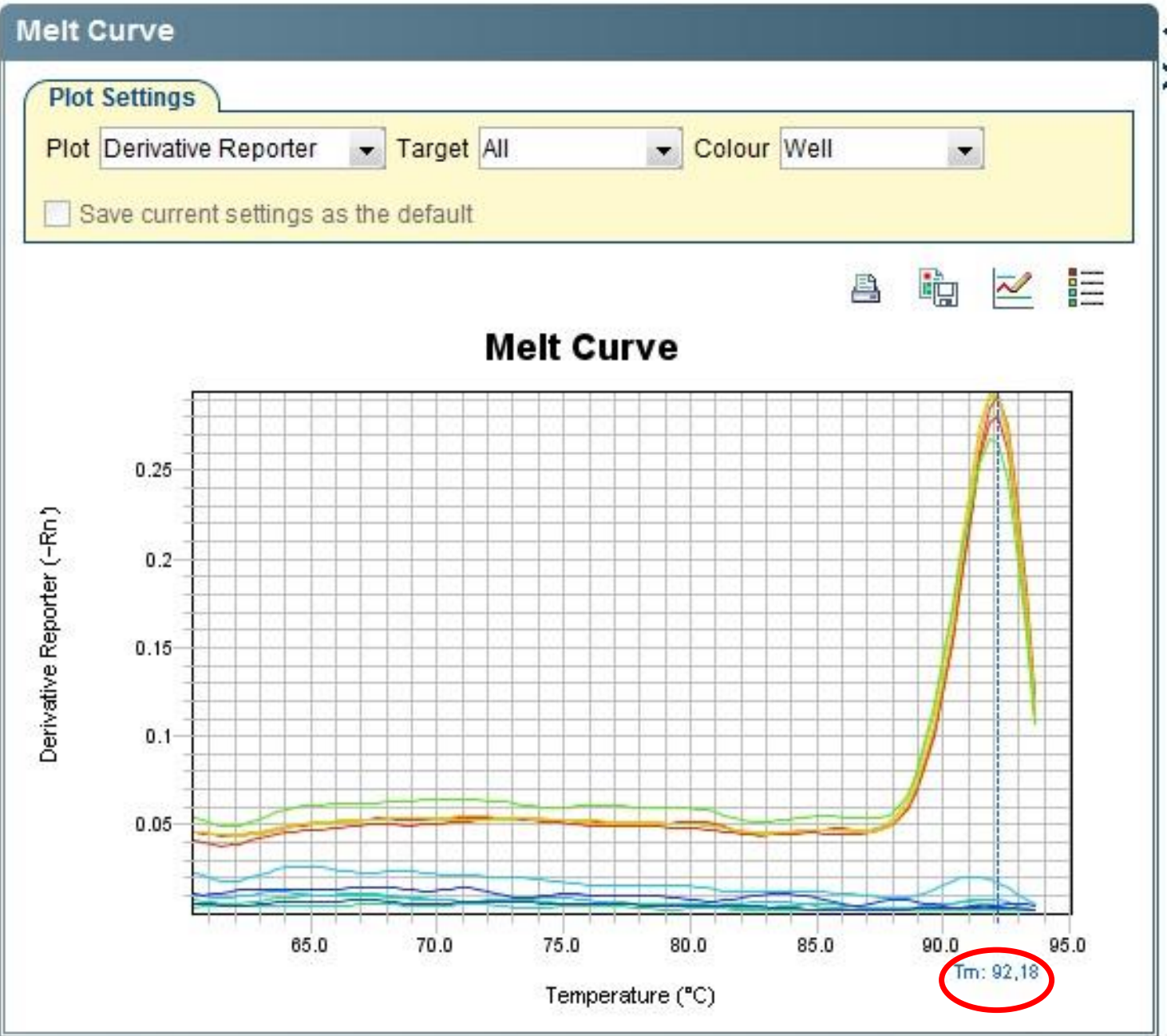

Figura 9 - Resultado da Curva Melting da Real-Time PCR- Dissociação da Dupla fita de DNA após a amplificação do DNA de Leishmania infantum-chagasi. 
Ao testarmos as amostras de DNA extraídos do sangue dos cães positivos, verificamos que a $\mathrm{TM}$ foi de $88,49^{\circ} \mathrm{C}$ (figura 10 ), apresentando $3^{\circ} \mathrm{C}$ de diferença das TMs apresentadas anteriormente para as amostras de DNA de cultura de Leishmania.

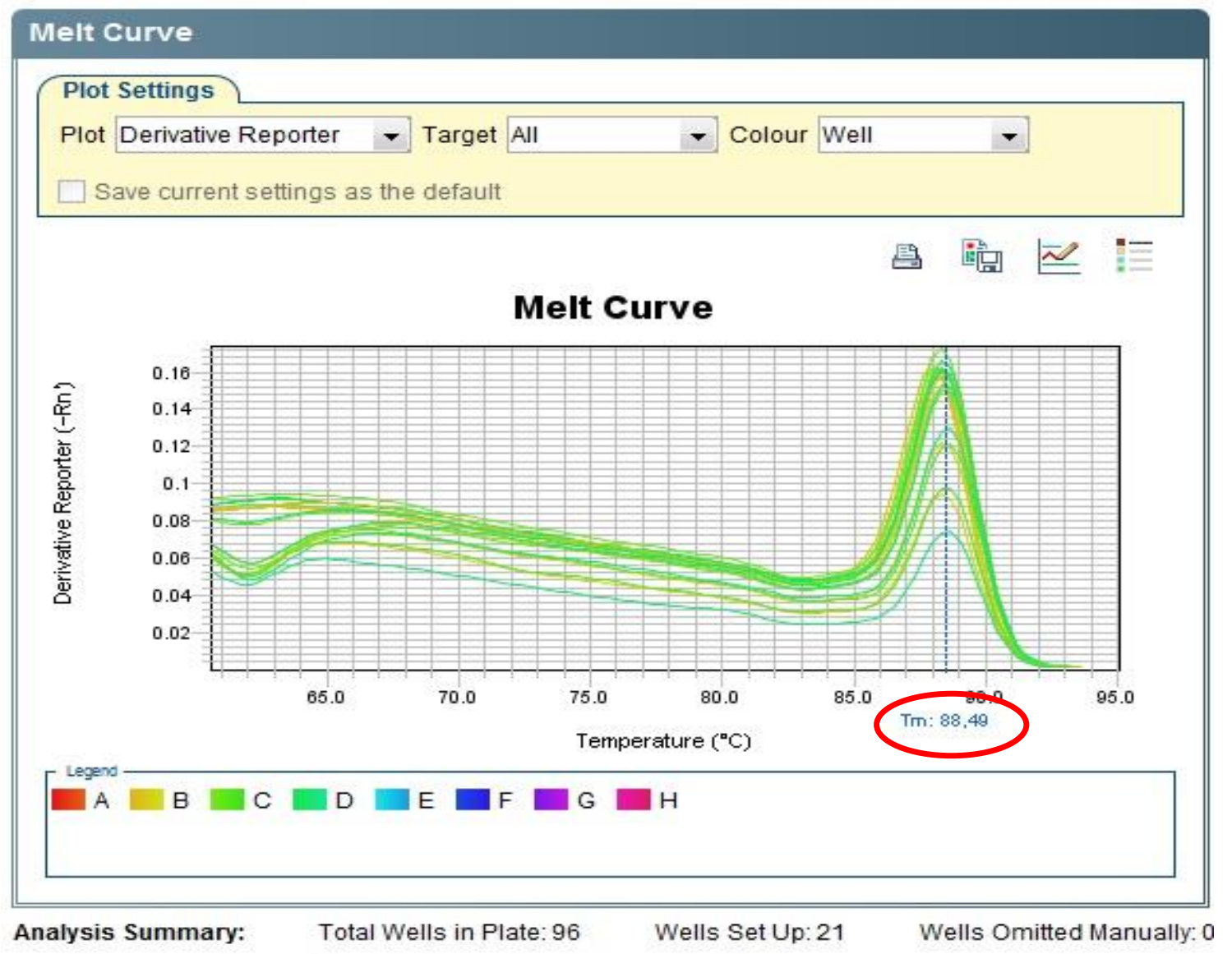

Figura 10 - Resultado da Curva de Melting da Real-Time PCR- Dissociação da Dupla fita de DNA após a amplificação do DNA de amostras de sangue dos cães soropositivos para LVC.

Por outro lado podemos perceber que a TM correspondente a dissociação da dupla fita de DNA de amostras provenientes da pele sem lesão, foram semelhantes as 
Martins TFC

TMs encontradas nas amostras de Leishmania em cultura de 92,16ํㅡ como demonstrado na figura 11. Desta forma, podemos sugerir que as amostras de sangue total possam conter outras patologias, pois o DNA amplificado não apresentou as mesmas características correspondentes ao DNA das Leishmanias testadas como padrão de reação.

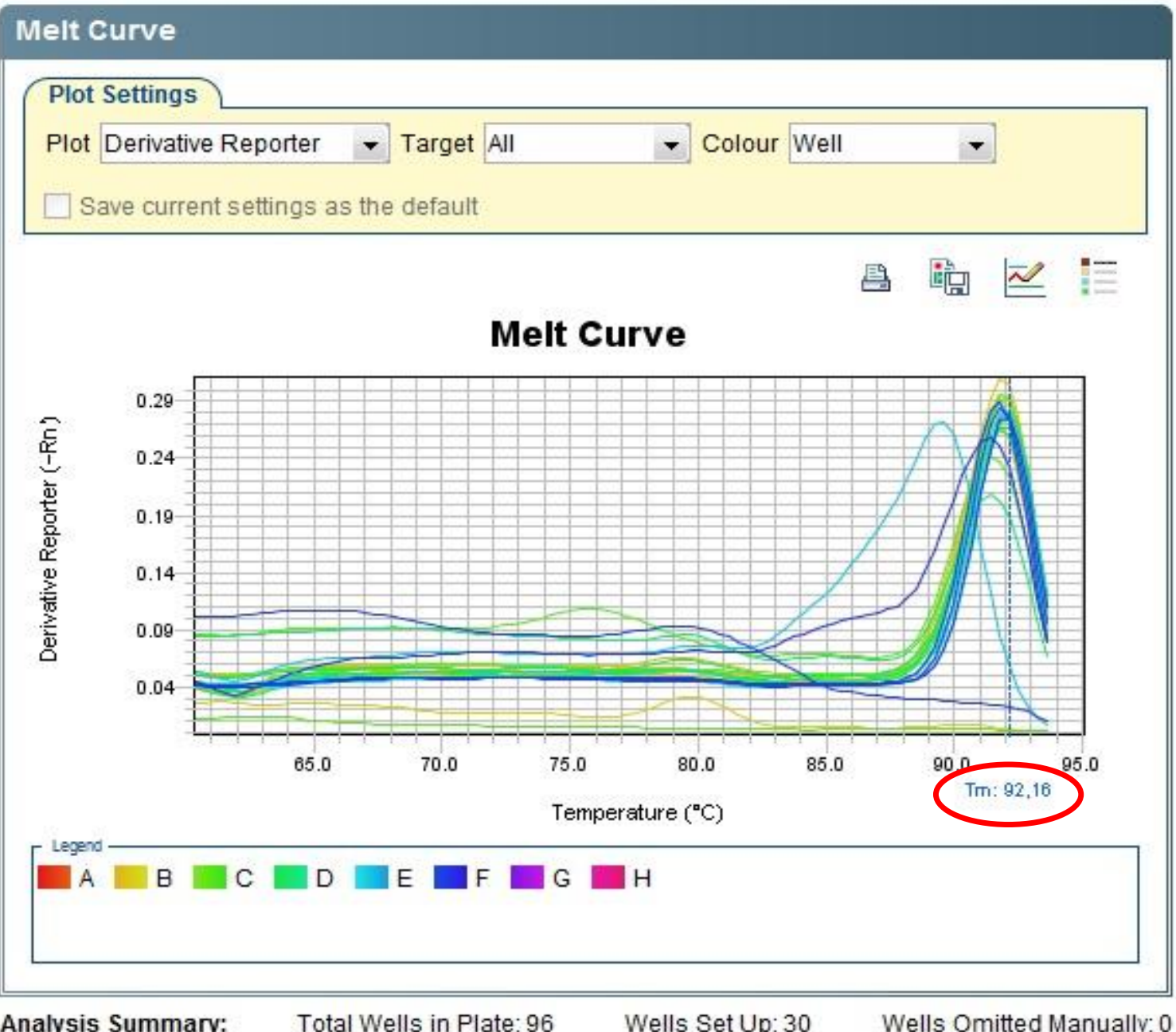

Figura 11 - Resultado da Curva de Melting da Real-Time PCR- Dissociação da Dupla fita de DNA após a amplificação do DNA das amostras dos tecidos de pele sem lesão coletadas dos cães com sorologia positiva para LVC. 
Martins TFC

\subsection{Resultados do Sequenciamento dos Produtos de PCR discordantes na Reação de kDNA-PCR:}

Os produtos da kDNA-PCR amplificados a partir das amostras de pele com lesão e eventualmente de baço dos cães EB015, EB016, EB023 e EB024 que apresentavam resultados considerados inconclusivos e negativos em todos os diferentes tecidos analisados, por todos os testes parasitológicos (tabela 8), foram sequenciados a fim de verificar se estes produtos eram correspondentes ao kDNA das Leishmania. Vale ressaltar que um produto de DNA proveniente de cultura de células promastigotas de Leishmania infantum-chagasi foi utilizado como controle do sequenciamento.

Infelizmente os resultados das reações de sequenciamento não foram conclusivos uma vez que as amostras utilizadas provavelmente continham algum tipo de inibidor (e não foi possível repetir o experimento). Mesmo assim, acreditamos que os produtos de amplificados de PCR sequenciados parecem ser sugestivos da espécie Leishmania. A comparação do produto amplificado com o DNA mitocondrial correspondente ao cinetoplasto das espécies de Leishmania, utilizando o programa online BLAST® Assembled RefSeq Genomes pertencente ao National Center for Biotechnology Information ( $\mathrm{NCBI}$ ), mostrou regiões de até 50 nucleotídeos com similaridade variando de $77 \%$ a $100 \%$ 


\section{DISCUSSÃO}

O diagnostico da Leishmaniose Visceral Canina (LVC) é de grande importância, não só para direcionar um tratamento mais eficaz como também para o controle da patologia nas áreas endêmicas. Como sabemos, um diagnóstico preciso é a base para o início do tratamento, pois a identificação da espécie do parasito está relacionada com a evolução da doença (Schönian et al., 2011).

Até o presente momento, não existe um consenso científico sobre como administrar o diagnóstico da LVC (Solano-Gallego et al., 2011), que ainda não está bem definido, ficando restrito a uma combinação de fatores que relacionam a distribuição geográfica, presença do vetor transmissor da doença, e manifestações clinicas, sendo necessária uma equipe de profissionais qualificados para determinarem o diagnóstico da Leishmaniose com precisão. Desta forma, os estudos relacionados com novas abordagens diagnósticas para LVC estão sendo desenvolvidos e apresentados como uma medida de urgência para o controle e tratamento da LVC ao redor do mundo.

Outra questão extremamente relevante quanto à identificação da Leishmaniose está relacionada com o controle e prevenção da doença, uma vez que já se sabe que a doença canina precede a doença humana. Apesar de não estar bem definida a relação do cão como reservatório para a Leishmaniose cutânea, já se sabe que alguns cães podem apresentar infecção por Leishmania (Viannia) como foi descrito nos trabalhos de Madeira e colaboradores (2003) e Ocampo e colaboradores (2011), porém, os cães 
já estão consagrados como os principais reservatórios urbanos para a Leishmaniose Visceral humana, a forma mais severa da doença.

Esse projeto de pesquisa foi desenvolvido na cidade de Embu das Artes-SP, que fica à apenas $23 \mathrm{~km}$ da cidade de São Paulo, a partir da avaliação de um inquérito sorológico realizado no local durante o período de 2002 a 2009. Neste inquérito, feito com supervisão do Instituto Adolpho Lutz de São Paulo, verificamos que os testes sorológicos (ELISA, utilizando o extrato total do parasito como insumo) indicavam a presença de 66 cães positivos para Leishmaniose em um universo de 2348 animais analisados. Interessantemente, estudos relacionados com a fauna vetorial (desenvolvidos concomitantemente na região pela SUCEN) não indicaram a presença do principal vetor relacionado com a transmissão da LVC, ou seja, verificou-se a ausência do flebotomíneo Lutzomyia longipalpis. Desta forma, propusemos um trabalho que avaliasse não só o tipo de infecção que estava ocorrendo na região de Embu das Artes, como também desenvolvesse um estudo comparativo entre alguns dos principais testes diagnósticos utilizados para a LVC, ou seja: os testes de cultura in vitro, pesquisa direta do parasito em lâminas coradas e a PCR.

Quando nosso grupo começou a acompanhar esse projeto (2009 a 2012), inicialmente desenvolvido pela Secretaria da Saúde do Município de Embu das Artes, sugerimos um protocolo desenvolvido pelo nosso laboratório para a coleta dos diferentes tecidos dos 26 cães avaliados nesse estudo (item 4.1 de materiais e métodos). Assim, todas as amostras utilizadas nesse projeto (baço, linfonodo, pele com e sem lesão, e sangue dos 26 cães eutanasiados) seguiram o mesmo padrão de coleta e armazenamento das amostras descrito pelo nosso protocolo, o que acreditamos ter refletido diretamente nos altos índices de positividade verificados após 
a realização dos testes de cultura in vitro (que atingiram cerca de $70 \%$ para o baço e linfonodos; tabela 2). Ao compararmos os resultados dos testes parasitológicos de cultura in vitro e pesquisa direta do parasito em lâminas coradas, percebemos que uma das conquistas desse trabalho foi o aumento da sensibilidade do teste de cultura in vitro, atingindo um índice de positividade de $69,23 \%$ de parasitos isolados em tecidos provenientes do baço e linfonodo, como apresentados na tabela 2. Considerando os resultados dos quatro tecidos analisados, conseguimos isolar o parasito de 19 (ou $73,07 \%)$ dos 26 cães avaliados.

Quanto aos índices de contaminação encontrados no teste de cultura in vitro, verificamos que dependendo do tecido analisado ele variava de $3,84 \%$ a $23,07 \%$ respectivamente em amostras provenientes do baço e da pele lesionada, o que pode ser explicado pela menor quantidade de contaminantes externos (fungos e bactérias) presentes nas amostras de órgãos internos. Esses dados foram confirmados pela análise estatística que mostrou que a utilização das amostras de baço e pele com lesão podem influenciar de forma significativa a sensibilidade do teste de cultura in vitro (teste $\chi^{2}$ com valor de $p=0,056$; item 5.3). Resultados semelhantes, porém com índices de positividade inferiores aos nossos, foram obtidos por Barrouin-Melo e colaboradores (2004) que compararam pelo teste de cultura in vitro o uso de amostras provenientes de baço e linfonodo extraídos de cães positivos para LVC, verificando respectivamente um índice de positividade de 56,2\% e 1,6\%.

Da mesma forma, os resultados provenientes da pesquisa direta de parasitos em lâminas coradas por Giemsa com os diferentes tecidos analisados também foram significantemente mais sensíveis quando comparados entre si nas amostras de baço e da pele com lesão, apresentando um índice de positividade de 73,08\% em ambas as 
amostras (tabela 3). Resultados semelhantes e também com índices de positividade inferiores aos obtidos pelo nosso grupo foram apresentados por Reis e colaboradores (2013), quando avaliaram de forma comparativa a eficiência de testes moleculares em relação os testes parasitológicos clássicos para o diagnóstico da LVC utilizando diferentes amostras de tecidos coletadas de cães provenientes de Belo Horizonte-MG. Enquanto os testes parasitológicos de pesquisa direta do parasito em lâminas coradas com Giemsa apresentados por Reis (2013) indicaram índices de positividade de 55,5\% e $8,3 \%$, respectivamente para o baço e a pele sem lesão, verificamos em nosso trabalho um índice de 73,08\% para ambos os tecidos (tabela 3).

A PCR foi o foco principal deste trabalho, pois além de ser considerada como um método rápido vem sendo amplamente utilizada para o diagnóstico das doenças infecciosas, apresentando índices bastante razoáveis de sensibilidade e especificidade. No caso específico da detecção do DNA de Leishmania, a PCR tem apresentado resultados promissores no sentido de conseguir discriminar a espécie do parasito envolvida na infecção (Marques et al., 2001; Castilho et al., 2003; Garcia et al., 2004; Zhang et al., 2006, da Silva et al., 2010; Montalvo et al., 2012).

Nossas reações de PCR convencional foram feitas com iniciadores dirigidos para dois alvos de DNA diferentes, sendo um voltado para o DNA mitocondrial do minicírculo do cinetoplasto (kDNA-PCR) e outro para o gene que codifica a enzima de choque térmico hsp70 (hsp70-PCR). Os resultados das amplificações das amostras dos diferentes tecidos avaliados por kDNA-PCR geraram índices de sensibilidade variando de $73,07 \%$ a $96,15 \%$, e de especificidade entre $91,30 \%$ a $100 \%$, quando comparados com os testes parasitológicos, que nesse caso foram considerados como padrão ouro pelas análises estatísticas (pelo teste de McNemar; tabela 11 e item 
5.6.1). Em consonância com os resultados anteriores, verificamos que a reação de kDNA-PCR com as amostras de pele com lesão e baço apresentaram respectivamente os maiores índices de sensibilidade (96,15\%) e especificidade (100\%) (tabela 11).

Entretanto, quando as amostras dos diferentes tecidos foram analisadas pela reação de hsp70-PCR, os índices de sensibilidade e especificidade obtidos após a análise estatística variaram respectivamente de $57,60 \%$ a $76,92 \%$ e de $73,91 \%$ a $86,96 \%$, mostrando claramente índices bem menores do que os verificados quando os DNAs dos mesmos tecidos foram amplificados pela reação de kDNA-PCR. De forma contrária ao observado com os outros testes realizados, as amostras que apresentaram maiores índices de sensibilidade e especificidade pela reação de hsp70PCR foram respectivamente, linfonodo (76.92\%) e ambos, linfonodo e pele sem lesão $(86,96 \%)$ (resultados - tabela 11). Essa fraca sensibilidade verificada em nossos resultados com a amplificação por hsp70-PCR também foi observada em trabalhos ainda não publicados pelo nosso grupo de pesquisa quando analisamos amostras de pacientes humanos com leishmaniose tegumentar, indicando que a utilização dessa tecnologia para análise de amostras clínicas precisa ser melhor estudada.

Andrade e colaboradores (2006) também utilizaram a reação de kDNA-PCR com diferentes amostras de tecidos de 39 cães naturalmente infectados na cidade de Belo Horizonte-MG. Os índices de sensibilidade apresentados por esse grupo foram semelhantes aos verificados em nosso trabalho. Enquanto o maior índice de sensibilidade verificado por Andrade (2006) foi de 87,2\%, obtido com amostras de pele, a reação de kDNA-PCR utilizando as amostras de pele com lesão em nosso trabalho mostraram um índice de sensibilidade superior de $96,15 \%$. Assim como o trabalho de Andrade (2006), Reis (2013), também analisou a eficiência da reação de PCR 
convencional em 60 cães soropositivos para LVC utilizando amostras de baço e pele desses cães, porém, Reis (2013) chegou a resultados que também foram um pouco inferiores aos obtidos no nosso estudo, no qual ele conseguiu os índices de sensibilidade para PCR convencional de apenas $73,3 \%$ para os dois tecidos.

Visando identificar a espécie de Leishmania em amostras clínicas, Volpini e colaboradores (2004) demonstraram que os produtos da digestão enzimática dos fragmentos amplificados pela kDNA-PCR com as enzimas de restrição Haelll e ApaLI, permitia a diferenciação entre algumas das espécies de Leishmania. Usando essa mesma estratégia nas amostras de tecido canino de Embu das Artes-SP, verificamos que utilizando apenas uma digestão enzimática com a enzima de restrição Haelll, (como observado na figura 2), conseguimos padrões enzimáticos diferentes com o DNA extraído de culturas de promastigotas de Leishmania amazonensis, Leishmania braziliensis e Leishmania infantum-chagasi.

A avaliação das amostras de DNA de tecido amplificadas por kDNA-PCR seguidas da digestão com Haell mostraram um perfil de clivagem semelhante ao apresentado pelo DNA das cultura de Leishmania infantum-chagasi. Dessa forma, foi possível inferir que a espécie envolvida na infecção canina da cidade de Embu das Artes era causada pela espécie Leishmania infantum-chagasi, em todos os tecidos dos cães avaliados. Esses resultados foram confirmados após a identificação da espécie de Leishmania infantum-chagasi através do teste de isoenzimas realizado pelo grupo de pesquisa da Profa. Elisa Cupolillo no Laboratório de Leishmaniose da FIOCRUZ, em todas as 19 amostras isoladas após a realização do teste de cultura in vitro. 
Analisando os resultados dos testes diagnósticos em cada cão (tabelas 8 e 9), constatamos ainda que três cães apresentaram resultados negativos em todos os testes parasitológicos realizados em todos os tecidos biopsiados, ou seja, foram realizados três testes diagnósticos diferentes com cada um dos tecidos testados, totalizando 12 análises diferentes para cada cão (cães EB012, EB016 e EB023). No cão EB023, verificamos que o resultado da amplificação do DNA de algumas amostras de tecido foram positivas apenas quando avaliadas por kDNA-PCR (baço, e pele com lesão) e por hsp70-PCR (pele com e sem lesão), sugerindo que nesse caso, a reação de PCR mostrou-se mais confiável do que os testes parasitológicos, até por que, além da sorologia positiva o cão era também sintomático.

Por outro lado, o cão EB016 só apresentou resultado positivo quando utilizamos as amostras de pele com lesão pela reação de kDNA-PCR. Vale ressaltar que todas as quatro amostras de tecido desse cão testadas pela reação de hsp70-PCR também apresentaram resultados negativos (tabelas 8 e 9). Nesse caso a reação de PCR pode ser colocada em dúvida, uma vez que foram obtidos 12 ensaios diferentes por testes parasitológicos com resultados negativos, além dos 4 ensaios realizados com o hsp70PCR e também 3 ensaios negativos com o kDNA-PCR (baço, linfonodo e pela sem lesão), sendo ainda importante enfatizar que o cão era assintomático. Dessa forma, os únicos resultados positivos para esse cão EB016 foram obtidos pela sorologia e pelo kDNA-PCR de amostras de pele com lesão.

De forma geral, ao analisarmos em conjunto os dados clínicos aliados aos resultados dos testes parasitológicos, e aos resultados da amplificação por PCR podemos chegar a conclusões mais próximas da realidade, como por exemplo, o que ocorreu com o cão EB012 que era assintomático. Como podemos verificar ( tabelas 8 e 
9), nenhuma amostra desse cão, analisada por todos os métodos utilizados nesse trabalho (ou seja, 20 ensaios diferentes), apresentou resultado positivo. Porem, este cão apresentou positividade para LVC apenas no teste sorológico, indicando que este teste pode apresentar resultados falso positivo. Portanto, acreditamos que esse cão provavelmente não apresentava LVC, e consequentemente não precisaria ser eutanasiado.

A partir dos resultados obtidos nas reações de PCR, utilizando as amostras de diferentes tecidos dos cães soropositivos, fizemos uma análise estatística para avaliar o índice de concordância entre os resultados dos testes parasitológicos com os resultados da kDNA-PCR. Essa análise foi feita de forma pareada entre os resultados das diferentes amostras dos cães, obtidos pelos dois testes. A avaliação dessa análise indicou que o índice de concordância, calculado pelo teste de McNemar, apresentou diferença estatisticamente significante quando utilizávamos os tecidos de pele com lesão (com valor de $p=0,041$; tabela 10 ), indicando que, a utilização dessa amostra influenciou a sensibilidade do teste de kDNA-PCR. Dessa forma, algumas amostras de DNA amplificado por kDNA-PCR, que apresentaram resultados positivos nos tecidos de pele com lesão e resultados negativos ou inconclusivos para os testes parasitológicos, foram sequenciadas com a finalidade de confirmar a presença do DNA de Leishmania nesse tecido, porém as sequencias de DNA obtidas infelizmente não apresentaram nenhum resultado conclusivo até o momento.

Apesar de termos utilizado amostras de cães sorologicamente negativos, como controle da reação de $\mathrm{PCR}$, provenientes da mesma região estudada, verificamos que seria ainda necessária a utilização de um grupo controle de cães sabidamente negativos para Leishmaniose, mas contendo outras parasitoses, como por exemplo, 
cães infectados por Trypanosoma caninum. Esse tripanosomatídeo que foi recentemente descritos por Madeira (2009) e Alves (2012) tem mostrado uma forte reação cruzada com os antígenos de Leishmania spp em testes sorológicos. Por se tratar de um tripanosomatídeo nós podemos supor que possa existir similaridade entre a sequencia de DNA desse tripanosomatídeo com o kDNA das Leishmanias.

Uma questão pertinente é referente à utilização do kDNA-PCR como diagnóstico de rotina para detecção do DNA de Leishmania. Será que a utilização dessa técnica, que é mais sensível, é de fato a melhor estratégia para o diagnóstico das Leishmanioses, ou a utilização de uma técnica mais específica, com alta capacidade discriminatória entre as espécies de Leishmania (como hsp70-PCR), seria mais apropriada?

Como muitos autores enfatizam que o diagnóstico da Leishmaniose é uma combinação entre o estudo clínico, epidemiológico e laboratorial (Sundar et al., 2002; Solano-Gallego et al., 2011), este projeto de mestrado compreendeu todos os setores do diagnóstico da LVC, incluindo a identificação da espécie de Leishmania envolvida na infecção canina da cidade de Embu das Artes. Desta forma podemos inferir que os testes sorológicos, até o presente momento, não deveriam ser aplicados sozinhos para a determinação da LVC. Por tanto, estamos sugerindo que os testes sorológicos devam ser associados com outros testes como, por exemplo, o teste kDNA-PCR, uma técnica relativamente simples que além de um diagnóstico mais apurado, permite também a diferenciação da espécie do parasito com uma única reação de digestão enzimática . 
Martins TFC

Sendo assim, acreditamos que a reação de kDNA-PCR pode ser utilizada como um teste de confiança para o diagnóstico da LVC, pois até o presente momento essa técnica apresenta uma alta sensibilidade, sendo capaz de detectar o DNA de Leishmania, mesmo em amostras de material clínico e biológico menos invasivas como a pele. Esperamos que nosso estudo possa contribuir significantemente para aprimorar o diagnóstico da LVC, assim como identificar as espécies de Leishmania de forma rápida e segura, além de colaborar com a padronização e implementação de novas técnicas diagnósticas para a determinação das Leishmanioses ao redor do Brasil e do mundo. 


\section{CONCLUSÕES}

Com estudos comparativos entre diferentes abordagens diagnósticas utilizando diferente tecidos de cães submetidos a várias análises metodológicas chegamos as seguintes conclusões:

1) A espécie de Leishmania infantum-chagasi foi identificada como sendo o agente causador da LVC na cidade de Embu das Artes.

2) A reação de kDNA-PCR foi o teste mais sensível para identificar a presença do parasito Leishmania em todas as amostras de tecido testadas, podendo ser utilizada como um teste de confiança para o diagnóstico da LVC.

3) Verificamos que um dos cães (o cão EB012), além de não apresentar nenhuma manifestação clínica, não apresentou nenhum indício da presença de parasito em nenhum dos testes realizados em qualquer dos tecidos avaliados, indicando que este cão não deveria ser eutanasiado.

4) A adoção de um protocolo bem estabelecido e com alto rigor no procedimento de coleta das amostras, permitiu obter um alto percentual de amostras de parasitos isolados em cultura in vitro (73,07\%) a partir dos diferentes tecidos coletados de cães eutanasiados.

5) Os testes parasitológicos diretos tem maior eficiência com amostras provenientes de órgãos internos, como por exemplo, tecidos de baço. Já para a reação de amplificação por PCR pode-se utilizar amostras menos invasivas, como por exemplo, amostras de pele. 


\section{REFERÊNCIAS}

Allahverdiyev AM, Bagirova M, Elcicek S, Koc RC, Oztel ON. Effect of Human Urine on Cell Cycle and Infectivity of Leismania Species Promastigotes In Vitro. Am. J. Trop. Med. Hyg. 2011; 85(4): 639-643.

Alencar JE,. Calazar canino: Contribuição para o estudo da epidemiologia do calazar no Brasil. Fortaleza, Imprensa Oficial. Tese da Universidade Federal do Ceará, 1959.

Andrade HM, Reis AB, Santos SL, Volpini CA, Marques JM, Romanha AJ. Use of PCRRFLP to identify Leishmania species in naturally-infected dogs. Veteinary Parasitology. 2006;140: 231-238.

Antinori S, et al. Clinical use of polymerase chain reaction performed on peripheral blood and bone marrow samples for the diagnosis and monitoring of visceral leishmaniasis in HIVinfected and HIV-uninfected patients: a single-center, 8-year experience in Italy and review of the literature. Clin Infect Dis. 2007; 44(12): 1602-1610.

Ashford RW. The leishmaniases as emerging and reemerging zoonoses. International Journal for Parasitology. 2000; 30 (12-13): 1269-1281.

Badaró R, Duarte MIS. Leishmaniose visceral (calazar). In: Veronesi R, Focaccia R, organizadores. Tratado de infectologia. São Paulo: Atheneu; 1996;1234:59.

Barrouin-Melo, SM, Larangeira DF, Trigo J, Aguiar PH, dos-Santos WL, Pontes-deCarvalho L. Comparison between splenic and lymph node aspirations as sampling methods for the parasitological detection of Leishmania chagasi infection in dogs. Mem. Inst. Oswaldo Cruz. 2004; 99:195-197.

Berman JD. Human Leishmaniasis: clinical, diagnostic, and chemotherapeutic developments in the last 10 years. Clinic Infect Dis.1997; 24(4):684-703

Brasil. Ministério da Saúde. Secretaria de Vigilância em Saúde. Guia de vigilância epdemiológica. Brasília (DF): Ministério da Saúde, 2009. [citado 2013 Outubro] 25p. Disponível em: -http://portal.saude.gov.br/saude/area.cfm?id_area=962. 
Borges MM, Campos-Neto A, Sleath P, Grabstein KH, Morrissey PJ, Skeiky YA, Reed SG. Potent stimulation of the innate immune system by a Leishmania brasiliensis recombinant protein. Journal of Am. Soc. for Microbiology. 2001; 69(9): 5270-5277.

Castilho TM, Shaw JJ, Floenter-Winter LM. New PCR assay using glucose-6-phosphate dehydrogenase for identification of Leishmania species. Journal of Clinical Microbiology, 2003; $41(2): 540-546$.

Casteilho TM, Camargo LM, McMahon-Pratt D, Shaw JJ, Floeter-Winter LM. A real-time polymerase chain reaction assay for the identification and quantification of AmericanLeishmania species on the basis of glucose-6-phosphate dehydrogenase. Am J Trop Med Hyg. 2008;78(1):122-32.

Cavalcanti A, Lobo R, Cupollilo E, Bustamante F, Porrozzi R. Canine cutaneous leishmaniasis caused by neotropical Leishmania infantum despite of systemic disease: A case report. Parasitolgy International. 2012; 61: 738-740.

Chargui NA, Haouas N, Jaouadi K, Gorcii M, Pratlong F, Dedet JP, Mezhound H, Babba H. Usefulness of a PCR-based method in the detection and species identification of Leishmania from clinical samples. Pathol Biol (Paris).2012; 60:75-79.

Cupolillo E, Brahim LR, Toaldo CB, de Oliveira-Neto MP, Falgueto A, de Farias Naiff M, Grimaldi G Jr. Genetic polymorphism and molecular epidemiology of Leishmania (Viannia) braziliensis from different hosts and geographic areas in Brazil. Journal of Clinical Microbiology. 2003; 41(7): 3126-3132.

Cortada VM, Doval ME, Souza Lima MA, Oshiro ET, Meneses CR, Abreu-Silva AL, Cupollilo E, Souza CS, Cardoso FO, Zaverucha do Valle T, Brazil RP, Gonçalves da Costa SC. Canine visceral leishmaniosis in Anastácio, Mato Grosso do Sul state, Brazil. Veterinary Research Communications. 2004; (10): 365-374.

da Costa CA, Genaro O, de Lana M, Magalhães PA, Dias M, Michalick MS, Melo MN, da Costa RT, Magalhães-Rocha NM, Mayrink W. Canine visceral leishmaniasis: evaluation of the serologic method used in epidemiologic studies. Rev. Soc Bras. Med. Trop. $199 ; 24(1): 21-25$.

da Silva L A, de Sousa Cdos S, da Graça GC, Porrozzi R, Cupolillo E. Sequence analysis and PCR-RFLP profiling of the hsp70 gene as a valuable tool for identifyin Leishmania 
species associated with human leishmaniasis in Brazil. Infection, Genetics and Evolution. 2010; 10:77-83.

de Queiroz NM, da Silveira RC, de Noronha AC Jr, Oliveira TM, Machado RZ, StrakeBuzetii WA. Detection of Leishmania (L.) chagasi in canine skin. Vet. Parasitology. 2011; 178: 1-8.

de Almeida ME, Steurer Fj, Koru O, Herwaldt BL, Pieniazek NJ, da Silva AJ. Identification of Leishmania spp. by Molecular Amplification and DNA sequencing Analysis of Fragment of rRNA internal transcribed spacer 2. J. Clin. Microbiol. 2011, 49(9):3143.

Degrave, W, Fernandes O, Campbell D, Bozza, M, Lopes U. Utilization of molecular probes and PCR for detection and typing of Leishmania-a mini-review. Mem. Inst. Oswaldo Cruz. $1994 ; 89: 463-469$.

Duarte MI, Mariano ON, Corbett CE. Liver parenchymal cell parasitism in human visceral leishmaniasis. Virchow Arch A Anat Histopathol. 1989; 415(1):1-6.

Feitosa MM, Ikeda FA, Luvizotto MCR, Perri SHV. Aspectos clínicos de cães com leishmaniose visceral no município de Araçatuba-São Paulo. Clinic. Vet. 2000; 28:36-44.

Ferrer L, Roura X, Sánchez A,. Diagnosis of canine leishmaniasis by a polymerase chain reaction technique. Vet Rec. 1999; 144(10):262-4.

Ferreira AW, Ávila SLM. Diagnóstico laboratorial das principais doenças infecciosas e autoimunes. Rio de Janeiro 2ª ed. Ed. Guanabara Koogan, 2001 ;255-262.

Floeter-Winter LM, Shaw JJ, Savani ES, de Oliveira Camargo MC, de Carvalho MR, Zampieri RA, dos Santos MG, D'Auria SR. The first record in the Americas of na auchthonous case of Leishmania (Leishmania) infantum chagasi in a domestic cat (Felix catus) from Cotia County, São Paulo State, Brazil. Vet. Parasitol. 2004; 120(3): 229-33.

Furtado T. Advances and perspectives in American cutaneous leishmaniasis. Rev. Mes Cutan Ibero Lat Am. 1987;15(2):105-116. 
Garcia L, Kindt A, Bermudez H, Llanos-Cuentas A, De Doncker S, Arevalo J, Wilber Quispe Tintaya K, Dujardin JC. Culture-independent species typing of neotropical Leishmania for clinical validation of a PCR-based assay targeting heat shock protein 70 genes. Journal of Clinical Microbiology. 2004; 42: 2294-2297.

Gomes YM, Cavalcanti MP, Lira RA, Abath FGC, Alves LC. Diagnosis of canine visceral leishmaniasis: biotechnological advances. The Veterinary Journal. 2006;31: 26-36.

Gontijo B, Carvalho MLR. American Cutaneous Leishmaniasis. Rev Soc Bras Med Trop. 2003; 36: 71-80.

Gontijo CMF, Melo MN. Leishmaniose visceral no Brasil: quadro atual, desafios e perspectivas, São Paulo. Ver. Bra. de Epidemiologia. 2004; 7(3).

Graça GC, Volpini AC, Romero GA, Oliveira Neto MP, Hueb M, Porrozzi R, Boité MC, Cupolillo E. Development and validation of PCR-based assays for diagnosis of American cutaneous leishmaniasis and identification of the parasite species. Mem Inst Oswaldo Cruz. 2012; 107(5)664-74.

Grandoni L, Gramiccia M. The current status of zoonotic leishmaniasis and approaches to disease control. Int. Journal for Parasitology. 2005; 35(11)1169-1180.

Hajjaran H, Vasigheh F, Mohebali M, Rezaei S, Mamishi S, Charedar S. Direct Diagosis of Leshmania Species on Serosity Materials Punctured From Cutaneous Leishmaniasis Patients Using PCR-RFLP, j. Clinical Laboratory Analysis. 2011; 25:20-24.

Keenan CM, Hendricks LD, Lightner L, Webster HK, Johnson AJ. Visceral Leishmaniasis in the German Shepherd dig. I. Infection, clinical disease, and clinical pathology. 1984; 21(1): 74-79.

Lamothe J, Poujade A. Ulcerative glossitis in dog with leishmaniasis. Vet Rec. 2002; 151(6):182-183.

Longoni SS et. al., An iron-superoxide dismutase antigen-based serological screening of dogs indicates their potential role in the transmission of cutaneous leishmaniasis and trypanosomiasis in Yucatan, Mexico. Vector-Borne and Zoonotic Dideases. 2011; 11 (7):815-821. 
Madeira, MF, Uchuôa, CMA., Leal CA, Silva RMM, Duarte R, Magalhães CM, Serra, CMB. Leishmania (Viannia) braziliensis em cães naturalmente infectados. Rev. Soc.Bras. Med. Trop. 2003; 36: 351-355.

Maia C, Campino L. Methods for diagnosis of canine lesihmaniasis and imune response to infection. Vet Parasitol. 2008;158(4):274-287.

Marfurt J, Nasereddin A, Niederwieser I, Jaffe CL, Beck HP, Felger I. Identification and differentiation of Leishmania species in clinical samples by PCR amplification of the miniexon sequence and subsequent restriction fragment length polymorphism analysis. J. Clin Microbiol. 2003; 41(7):3147-53.

Marques MJ, Volpini AC, Genaro O, Mayrink W, Romanha AJ. Simple form of clinical sample preservation and Leishmania DNA extraction from human lesions for diagnosis of American cutaneous leishmaniasis via polymerase chain reaction. Am. J. Trop. Med. Hyg. 2001; 65(6): 902-906.

Manual de Vigilância e Controle da Leishmaniose Visceral Americana do Estado de São Paulo / Coordenação Vera Lucia Fonseca de Camargo-Neves - São Paulo: A Secretaria, 2006.

Medeiro AR, Silva WA Jr, Roselino AM. DNA sequencing confirms the involvement of Leishmania (L.) amazonensis in American tegumentary leishmaniasis in the state of São Paulo, Brazil. Clinics. 2008;64: 451-456.

Mohammadiha A, Mohebali M, Haghighi A, Mahdian R, Abadi AR, Zarei Z, Yeganeh F, Kazemi B, Taghipour N, Akhoundi B. Comparison of real-time PCR and conventional PCR with two DNA targets for detection ofLeishmania (Leishmania) infantum infection in human and dog blood samples. Exp. Parasitol. 2013;133(1):89-94.

Mohammed EA, Wright EP, Kager PA, Laarman JJ, Pondman KW. ELISA using intact promastigotes for immunodiagnosis of Kala-azar. Trans. R Soc. Trop Med Hyg. 1985; 79(3):344-350.

Montalvo MA, Fraga J, Maes I, Dujardin JC, Van der Auwera G. Three new sensitive and specific heat-shock protein 70 PCRs for global Leishmania species identification. Eur J. Clin. Microbiol Infect Dis. 2012; 31:1453-1462. 
Nunes MC, Pires MM, da Silva KM, Assis FD, Gonçalves Filho J, Perri SH. Relationship between dog culling and incidence of human visceral leishmaniasis in an endemic area. Veterinary Paasitology, 2010;170:131-133.

Neves DP. Ocorrência de Leishmaniose visceral em um cão em Uberaba em um cão em Uberaba, Minas Gerais. Parasitologia humana. 2007; 47-66.

Ocampo CB, Santaella J, Saravia NG, Méndez F, Góngora R, Gomez MA, Munstermann LE, Quinnell RJ. Leishmania (Viannia) infection in the domestic dog in Chaparral, Colombia. Am J Trop Med Hyg. 2011; 84(5)674-680.

Organização Mundial de Saúde. Data needed on people infected with visceral leishmaniasis: call for expansion of working database. Geneva: World Health Organization: WHO Disponível em:http://www.who.int/leishmaniasis/burden/magnitude/burden magnitude/en/index.html; http://www.who.int/emc/diseases/leish/leisgeo1/html; acesso em Outubro 2013.

Organização Mundial de Saúde. Progress in the characterization of venoms and standardization of antivenoms. Geneva: World Health Organization: WHO - Disponível em:http://www.who.int/leishmaniasis/burden/magnitude/burden magnitude/en/index.html;

acesso Out. 2013

Organização Mundial de Saúde. Brazil, basic country data population. Geneva: World Health Organization: WHO http://www.who.int/leishmaniasis/resources/BRAZIL.pdf; acesso Out. 2013

Oryan A, Shirian S, Tabandeh MR, Hatam GR, Randau G, Daneshbod Y. Genetic diversity of Leishmania major strains isolated from different clinical forms of cutaneous leishmaniasis in southern Iran based on minicircle kDNA. Infect Genet Evol. 2013; 19:226-231.

Peleg O, Baneth G, Eyal O, Inbar J, Harrus S. Use of Chimeric DNA-RNA Primers in Quantitative PCR for Detection of Ehrlichia canis and Babesia canis. Am. Soc. Microbiology, Oct. 2009; 75(19): 6393-6398.

Quaresma PF, Murta SM, Ferreira Ede C, da Rocha-Lima AC, Xavier AA, Gontijo CM. Molecular diagnosis of canine visceral leishmaniasis: Identification of Leishmania species by PCR-RFLP and quantification of parasite DNA by real-time PCR. Acta Tropica. 2009; 111:289-294. 
Reis LES et al. Molecular diagnosis of canine visceral leishmaniasis: A comparative study of three methods using skin and spleen from dogs with natural Leishmania infantum infection. Veterinary Parasitology. 2013; 197:498-503.

Reithinger R, Dujardin JC. Molecular diagnosis of leishmaniasis: current status and future applications. J Clin Microbiol. 2007; 45(1):21-5.

Rey L. Parasitologia. 3로 ed. Rio de Janeiro: Guanabara Koogan; 2001.

Romero HD, Silva LA, Silva-Vergara ML, Rodrigues V, Costa RT, Guimarães SF, Alecrim W, Moraes-Souza H, Prata A. Comparative study of serologic tests for the diagnosis of asymptomatic visceral leishmaniasis in an endemic area. Am J Trop Med Hyg. 2009; 81: 27-33.

Saiki RK, Scharf S, Faloona F, Mullis KB, Horn GT, Erlich HÁ, Arnheim N. Enzymatic amplification of beta-globin genomic sequences and restriction site analysis for diagnosis of sickle cell anemia. Science. 1985; 230(4732):1350-4.

Santaella J, Ocampo CB, Saravia NG, Méndez F, Góngora R, Gomez MA, Munstermann LE, Quinnell RJ. Leishmania (Viannia) Infection in the Domestic Dog in Chaparral, Colombia. Am. J. Trop. Med. Hyg. 2011; 84(5): 674-680.

Schönian G, Kuhls K, Mauricio IL. Molecular approaches for a better understanding of the epidemiology and population genetics of Leishmania. 2011;138(4):405-425.

Singh SP, Picado A, Boelaert M, Gidwani K, Andersen EW, Ostyn B, Meheus F, Rai M, Chappuis F, Davies C, Sundar S. The epidemiology of Leishmania donovani infection in high transmission foci in India. Trop Med Int Health. 2010; 2:12-20.

Sivakumar R, Singh S. Recent advances in the diagnosis of leishmaniasis. J. Postgrad Med. 2003; 49(1):55-60.

Solano-Gallego L, et al. LeishVet guidelines for the practical management of canine leishmaniosis. Parasites and Vectors. 2011;4:86.

Srividya G, Kulshrestha A, Singh R, Salotra P, 2012. Diagnosis of visceral Leishmaniasis: developments over the last decade. Parasitol Res 110: 1065-1078 
Sundar S, Rai M, 2002. Laboratory diagnosis of visceral leishmaniasis. Clin Diagn Lab Immunol 9: 951-958.

Tafuri WL, de Oliveira MR, Melo MN, Tafuri WL. Canine Visceral Leishmaniosis: a remarkable histopathological Picture o fone case reported from Brazil. Vet. Parasitol 2001; 96(3):203-212.

Toz SO, Culha G, Zeyrek FY, Ertabaklar H, Alkan MZ, Vardarli AT, Gunduz C, Ozbel Y. A real-time ITS1-PCR based method in the diagnosis and species identification of Leishmania parasite from human and dog clinical sample in Turkey. PloS Negl. Trop. Dis. 2013;

Volpini AC, Passos VM, Oliveira GC, Romanha AJ. PCR-RFLP to identify Leishmania (Viannia) braziliensis and L. (Leishmania) amazonensis causing American cutaneous leishmaniasis. Acta tropica. 2004; 90: 31-37.

Venazzi EAS, Roberto ACBS, Barbosa-Tessmann IP, Zanzarini PD, Lonardoni MVC, et al. (2006) Polymerase chain reaction with lesion scrapping for the dianosis of human American tegumentary leishmaniasis. Mem Inst Oswaldo Cruz 101: 427-430.

Weigle KA, Labrada LA, Lozano C, Santrich C, Barker DC. PCR-based diagnosis of acute and chronic cutaneous leishmaniasis caused by Leishmania (viannia). J. Clin. Microbiol. 2002; 40(2):601-606.

Weirather JL, et al. Serial quantitative PCR assay for detection, species discrimination, and quantification ofLeishmania spp. in human samples.J. Clin. Microbiol. 2011; 49(11): 3892904.

Zanzarini PD, dos Santos DR, dos Santos AR, de Oliveira O, Poiani LP, Lonardoni Mv, Teodoro U, Silveira TG. Canine American cutaneous leishmaniasis in municipalities of northern Paraná State, Brazil. Cad. Saude Publica. 2005; 21(6): 1957-61.

Zhang WW, Miranda-Verastegui C, Arevalo J, Ndao M, Ward B, Llanos-Cuentas A, Matlashewski G. Development of a genetic assay to distinguish between Leishmania viannia species on the basis of isoenzyme differences. Clin. Infect. Dis. 2006; 42(6):801809. 


\section{ANEXO A - Comitê de Ética do IMT/ USP}
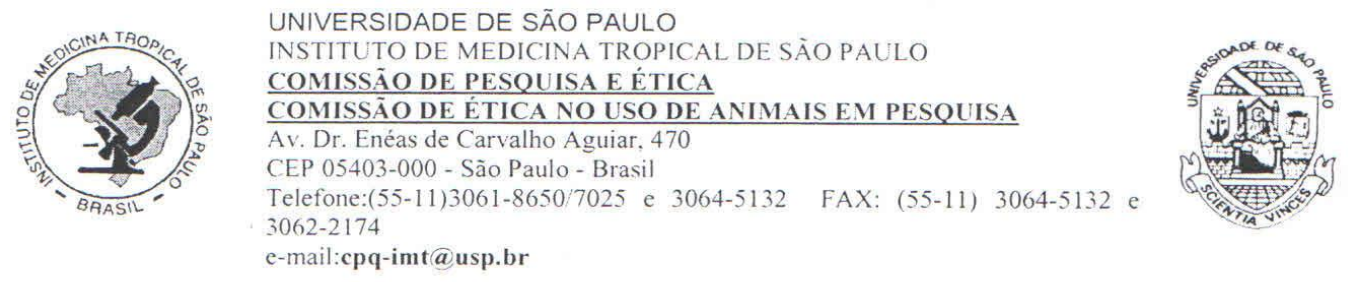

São Paulo, 29 de fevereiro de 2012.

IImo (a)

Dr. Paulo Cotrim

(aos cuidados de Thaynan Fernandes Cunha Martins)

Em reunião na presente data, a Comissão de Pesquisa e Ética e Comissão de Ética no Uso de Animais em Pesquisa, do Instituto de Medicina Tropical de São Paulo, analisou e aprovou, no que diz respeito aos aspectos de natureza da ética em experimentação animal, o projeto de pesquisa classificado sob número CPE-IMT 2011/104 e intitulado "Análise da eficiência da PCR com identificação específica do agente etiológico para o diagnóstico da Leishmaniose Visceral Canina no Município de Embu das Artes", sob a sua responsabilidade.

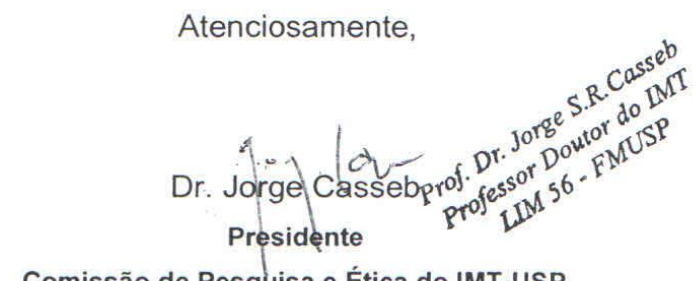

Comissão de Pesquisa e Ética do IMT-USP

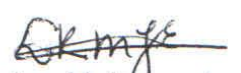

Dra. Luciana Regina Meireles Jaguaribe Ekman

Coordenadora da Comissão de Ética no Uso de Animais em Pesquisa do IMT-USP 